\title{
REGULATING YOUTH ACCESS TO VIOLENT VIDEO GAMES: THREE RESPONSES TO FIRST AMENDMENT CONCERNS
}

\author{
Kevin W. Saunders \\ 2003 L. REV. M.S.U.-D.C.L. 51
}

TABLE OF CONTENTS



I. VIDEO GAMES AND REAL WORLD VIOLENCE - MEETING

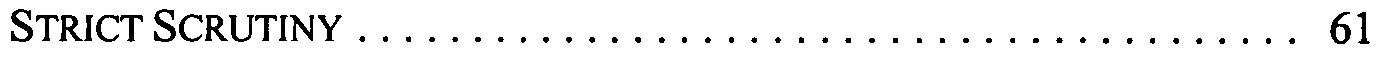

A. Research on the Effects of Violence in Other Media . . . . . 62

B. Causation and Video Games ................. 71

C. The Training and Instructional Danger of Video Games $\ldots .76$

D. Meeting Strict Scrutiny $\ldots \ldots \ldots \ldots \ldots \ldots \ldots \ldots \ldots \ldots \ldots$

II. VIOLENCE AS OBSCENITY $\ldots \ldots \ldots \ldots \ldots \ldots \ldots \ldots \ldots \ldots \ldots \ldots$

A. The Ordinary Language Concept $\ldots \ldots \ldots \ldots \ldots \ldots \ldots . \ldots$

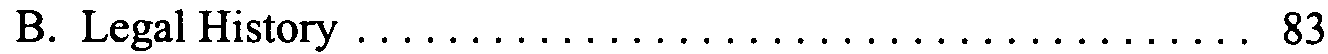

C. Policy Bases ....................... 85

D. Children and Variable Obscenity $\ldots \ldots \ldots \ldots \ldots \ldots \ldots 87$

E. Obscenity and Offence $\ldots \ldots \ldots \ldots \ldots \ldots \ldots \ldots . \ldots \ldots$

III. VIDEO GAMES AS UNPROTECTED BY THE FIRST AMENDMENT $\ldots . .93$

A. Early Video Games $\ldots \ldots \ldots \ldots \ldots \ldots \ldots \ldots \ldots \ldots$

B. Modern Games $\ldots \ldots \ldots \ldots \ldots \ldots \ldots \ldots \ldots \ldots \ldots$

C. Improved Story Lines Not Enough $\ldots \ldots \ldots \ldots \ldots \ldots \ldots$

D. Video Games as Non-communication . . . . . . . . . . . . 101

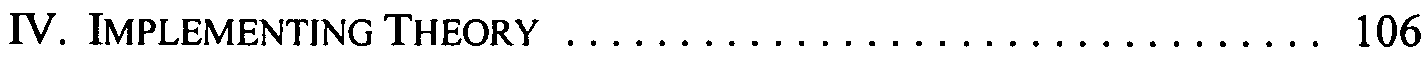

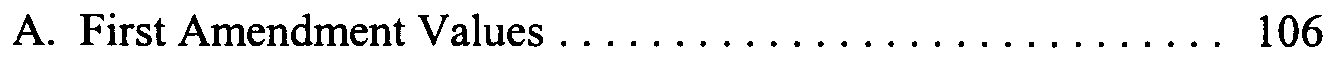

B. Drafting Statutes ...................... 108

1. Statutes Based on Harm ................... 109

2. Statutes Based on Violence as Obscene ........... 110

3. Statutes Based on Video Games as Unprotected ....... 113

CONCLUSION ............................ 113

* Professor of Law, Michigan State University-Detroit College of Law. A.B., Franklin \& Marshall College; M.S., M.A., Ph.D., University of Miami; J.D., University of Michigan. This effort was supported by a research grant from Michigan State University-Detroit College of Law. After submission of this paper, the Lion \& Lamb project requested the author to write an Amicus Curiae Brief for the pending Interactive Digital Software Ass' $n v$. St. Louis County, No. 02-3010, appeal in the Court of Appeals for the Eighth Circuit. 


\section{INTRODUCTION}

American's concern over media violence, formerly directed toward television and film, ${ }^{1}$ has recentered over the past several years on violence in video games. This refocusing followed on the heels of several school shootings in which video games were seen as playing a role. The most horrific of these events, and the one that really seemed to put the issue in the spotlight, was the 1999 Columbine High School killings in Colorado; but even before that massacre, there had been approximately two hundred American children killed in "school associated violence" between 1992 and 1998. ${ }^{2}$

The details of the murderous spree of Dylan Klebold and Eric Harris at Columbine High can be found at a variety of sources. ${ }^{3}$ The tie to video games is found in the fact that Harris and Klebold were said to play violent video games for hours and were fanatics with regard to the video game Doom. ${ }^{4}$ Harris had even modified Doom on his computer to make him, as the player,

1. As early as 1992, a Times Mirror poll found seventy-two percent of Americans expressing the sentiment that television is too violent. See Charles S. Clark \& Mary H. Cooper, TV Violence, 3 CQRESEARCHER 265, 268 (1993). This concern reflected the findings of a 1986 study by the American Psychological Association's task force on television and society that concluded that by the time the average child finishes elementary school, the child has viewed over eight thousand murders and over one hundred thousand other acts of violence, and depending on viewing habits, may have seen as many as two hundred thousand acts of violence, before becoming a teenager. See AlETHA C. HuSTON ET AL., BIG WORLD, SMALL SCREEN: THE Role of TElEVISION IN AMERICAN SOCIETY 53-54 (Gary B. Melton \& Carolyn Stineman Schroeder eds., 1992).

2. The calculation is that of Ronald Stephens, director of the National School Safety Center. See Understanding Violent Children: Hearing Before the Subcomm. on Early Childhood, Youth and Families of the House Comm. on Educ. and the Workforce, 105th Cong. (1998) (testimony of Ron Stephens), available at http://commdocs.house.gov/committees/edu/ hedcew5-97.000/hedcew5-97.htm\#_Toc434653165.

3. See, e.g., Lynn Bartels \& Ann Imse, Friendly Faces Hid Kid Killers: Social, Normal Teens Eventually Harbored Dark, Sinister Attitudes, DENVER ROCKY MOUNTAIN NEWS, Apr. 22, 1999, at 10A; Mark Obmascik, Healing Begins: Colorado, World Mourn Deaths at Columbine High, THE DENVER Post, Apr. 22, 1999, at 1 A; Norm Clarke, Luck and a Lie Saved Wrestler: Teen's Shamrock Cap His 'Lucky Charm, 'DENVER ROCKY MOUNTAIN NEwS, Apr. 22, 1999, at A14; Mike Anton, Death Goes to School with Cold, Evil Laughter, DENVER ROCKY MOUNTAIN NEWS, Apr. 21, 1999, at 2A; Tina Griego et al., Quiet Loners Worried Other Students: Trench Coat Mafia Spoke about Violence, Carried Reputation for Being Outsiders, DENVER ROCKY MOUNTAIN NEWS, Apr. 21, 1999, at 6A; Mark Eddy, Shooter Told Friend: "Get out of Here", THE DENVER POST, Apr. 21, 1999, at 17A.

4. See Burt Hubbard, Researchers Say Harris Reconfigured Video Game: Boy Turned

'Doom' into School Massacre, Investigators Claim, DENVER ROCKY MOUNTAIN NEWS, May 3,1999 , at $1 \mathrm{~A}$. 
invincible and with unlimited weaponry and ammunition. The game became one in which "[t]he player simply mows down all the other characters." His modification also had some of the dying victims asking God why they were shot, ${ }^{6}$ a scenario at least somewhat similar to a query Harris and Klebold put to some victims at Columbine as to whether or not they believed in God. A video tape also shows one of the killers calling his shotgun "Arlene," a favorite character in Doom. ${ }^{7}$

Earlier school shootings showed similar connections to video games. In 1997, in remote Bethel, Alaska, Evan Ramsey, a high school student, killed two and wounded two others. ${ }^{8} \mathrm{He}$, too, enjoyed violent video games, playing Doom, Die Hard, and Resident Evil for hours at a time. ${ }^{9}$ Ramsey, who had little real experience with fire arms, placed some blame on the games, saying they taught him that being shot does not cause death but a reduction in the player's "health factor." 10 One of the strongest cases can be made in the shootings by Michael Carneal at Heath High School in the Paducah, Kentucky area." Carneal came to school one morning with a .22 caliber semiautomatic pistol, two rifles, and two shotguns and began shooting at a prayer group whose meeting was just breaking up. ${ }^{12}$ He killed three and wounded five. ${ }^{13}$ Carneal also enjoyed playing Doom, as well as other violent video games such as Quake and Redneck Rampage. ${ }^{14}$

5. Id.

6. See id.

7. See Associated Press, 'Doom' Defendants: Dismiss Suit, The DenVer Post, Aug. 29,2001 , at $3 \mathrm{~B}$.

8. For a description of the Bethel shootings, see Tom Bell \& Rosemary Shinohara, Student Kills 2 in Bethel: Frightened Teens Flee High School, ANCHORAGE DaILY NewS, Feb. 20,1997 , at A-1.

9. See Steve Fainaru, Experts Fear Video Games Breed Violence, ANCHORAGE DAILY News, Nov. 9, 1998, at A-1.

10. See id.

11. See Ted Bridis, Praying Students Slain, LeXINGTOn Herald-LEAder, Dec. 2, 1997, at Al.

12. See id.

13. See id.

14. For assertions of the role of video games in the Heath High School killings see James v. Meow Media, Inc., 90 F. Supp. 2d 798 (W.D. Ky. 2000), aff'd, 300 F.3d 683 (6th Cir. 2002), cert. denied, U.S. _ 123 S. Ct. 967 (2003); DAVE GROSSMAN \& GloRIA

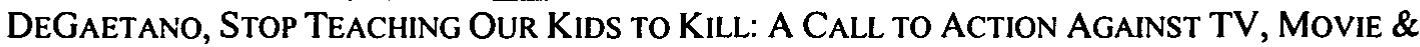
Video Game Violence (1999); John Cheves, Do Violent Images Cause Violent Action? Heath Parents' Lawsuit Must Prove Direct Link, LEXINGTON HERALD-LEADER, May 2, 1999, at A1; James Prichard, Suit Blames Hollywood, Net for Heath Shootings, LEXINGTON HERALDLEADER, Apr. 13, 1999, at A1. 
While many may be skeptical of the ability of violent media to make a good child go so bad, and indeed the killers in most of the school cases seemed troubled, there is an additional factor in the Paducah case that should give pause to even those most doubting as to psychological influences. According to his lawyer, Carneal had "no appreciable exposure to firearms."15 Yet, with eight ${ }^{16}$ or nine ${ }^{17}$ shots, he had eight hits, all in the head or upper torso. Such accuracy with a handgun, especially for an inexperienced marksman, is astounding. "The FBI says that the average experienced law enforcement officer, in the average shootout, at an average range of seven yards, hits with approximately one bullet in five." 18 How then did a fourteenyear-old manage five head shots and three in the upper torso ${ }^{19}$ It appears to have been his video game training that made him an effective killer.

[Carneal] never moved his feet during his rampage. He never fired far to the right or left, never far up or down. He simply fired once at everything that popped up on his "screen." It is not natural to fire once at each target. The normal, almost universal, response is to fire at a target until it drops and then move on to the next target. This is the defensive reaction that will save our lives, the human instinctual reactioneliminate the threat quickly. Not to shoot once and then go on to another target before the first threat has been eliminated. But most video games teach you to fire at each target only once, hitting as many targets as you can as fast as you can in order to rack up a high score. And many video games give bonus effects . . . for head shots. $^{20}$

One does not have to accept the notion that media violence causes actual violence to see a relationship here. Whatever may have caused Carneal to be motivated to kill, video games appear to have given him the skills and reactions to accomplish his goal.

The next shooting in the series, this one in Jonesboro, Arkansas, also implicates video games. Mitchell Johnson, a thirteen-year-old, and Andrew Golden, an eleven-year-old, stole nine or ten guns from the Golden family, took at least four of them, two pistols and two hunting rifles, to their middle school and killed four girls and a teacher and wounded ten others. ${ }^{21}$ The boys took up a position at the edge of a wooded area next to the school. One of them set off a fire alarm and then returned to their vantage point. As the children filed out of the school in response to the alarm, they used high

15. Cheves, supra note 14 , at *3.

16. See id.; Grossman \& DeGaetano, supra note 14, at 75-76.

17. See Prichard, supra note 14.

18. GROSSMAN \& DEGAETANO, supra note 14, at 4.

19. For the locations of the wounds see $i d$.

20. Id. at 75-76.

21. See Rick Bragg, Arkansas School Ambushed, ATLANTA CONST., Mar. 25, 1998, at Al. 
powered rifles to fire at their targets, who were unable to flee to the safety of the school building because of automatic locks to prevent entry during a fire.

Both boys played violent video games, ${ }^{22}$ and the games may have provided effective training. While one of the boys did have experience with real weapons, there is no indication of similar experience for the other. Again, their accuracy and effectiveness were astounding.

These two avid video game players fired a combined total of twenty-seven shots from a range of over one hundred yards, and hit fifteen people. They strategically trapped their victims, lined them up, and shot with deadly accuracy. Battle-scarred veterans and military analysts reacted with amazement at the accuracy of their shooting, on one hand, and the military strategy involved in setting up their "kill zone," on the other. Both skills are taught by an array of home and arcade video games. ${ }^{23}$

Aside from any effect of violent media in psychological development, the skills taught implicate video games in the killings.

If video games are causing or contributing to the effectiveness of juvenile mass murderers, the effect may have just begun. While increased school security and limitations on the access of juveniles to firearms may reduce the likelihood of similar events, the effects of violent video games may well grow. Violent television and films have been with us for some time, and studies show a link to violence in the real world. ${ }^{24}$ Interestingly, the long-term effect may have a multi-year gap, with the growth of violence coming years after the exposure of children to media violence. ${ }^{25}$ For television that gap was in the neighborhood of fifteen years. Violent, first person shooter video games have not been with us anywhere near that long. If a similar gap exists for those games, the real growth in video game induced violence has yet to come.

The issue of whether or not violent video games, and other violent media, do cause real world violence or otherwise harm the physical or psychological development of children will be discussed in the next section. It is sufficient here to note that concerns over such effects have been sufficient to motivate legislation aimed at controlling the exposure of minors to video game violence. Two jurisdictions have passed such legislation and others have considered similar limitations.

In July 2000, the combined city and county council for the City of Indianapolis and Marion County adopted General Ordinance No. 72, which required that video arcades, with five or more games, take steps to limit access

22. See Timothy Egan, Killing Sprees Tied by String of Youth Rage, THE DENVER POST, June 14, 1998, at $1 \mathrm{~A}$.

23. GROSSMAN \& DeGAETANO, supra note 14, at 76-77.

24. See infra notes 57-98 and accompanying text.

25. See infra notes 74-76 and accompanying text. 
by minors, defined as those under eighteen, to games that are "harmful to minors." ${ }^{26}$ Arcades had to separate games that are harmful to minors from other games and only allow children under eighteen to play if accompanied by a parent, guardian, or custodian. The ordinance also defined games that are "harmful to minors" as games with graphic violence or strong sexual content that appeal predominantly to minors' morbid interest in violence or prurient interest in sex, that are patently offensive under the standards of the adult community as to what is suitable for minors, and that taken as a whole lack serious literary, artistic, political, or scientific value for minors. "Graphic violence" was further defined as the "depiction or representation of realistic serious injury to a human or human-like being where such serious injury includes amputation, decapitation, dismemberment, bloodshed, mutilation, maiming or disfiguration." 27

In October 2000, St. Louis County, Missouri passed a similar ordinance. Ordinance No. 20,193, like the Indianapolis ordinance, required that video arcade operators separate games that are "harmful to minors." 28 Minors could not be admitted to the area containing such games, without the permission of a parent or guardian, nor could retailers sell or rent such video games to a minor not accompanied by a parent or guardian. "Harmful to minors" was defined so as to include the same sort of violent depictions addressed by the Indianapolis ordinance. The St. Louis ordinance did, however, address only a somewhat younger audience, those under seventeen. It also contained a rebuttable presumption that games rated by the video game industry's Entertainment Software Review Board as "M," for mature, or "AO," for adults only, are harmful to minors, while games rated "E," for everyone, "EC," for early childhood, or " $T$," for teen, are rebuttably presumed not to be harmful to minors. A similar rebuttable presumption applied to the alternative rating system developed by an industry group including the American Amusement Machines Association. "Red" rated games are presumed harmful, while "yellow" and "green" rated games are presumed not harmful to minors.

Other jurisdictions considered similar ordinances but failed to enact them into law. A bill was introduced in the Oregon State Senate to limit

26. The text of the ordinance is set forth in a case challenging its constitutionality. See Am. Amusement Mach. Ass'n v. Kendrick, 115 F. Supp. 2d 943, 946-47 (S.D. Ind. 2000) [hereinafter Am. Amusement Mach. I], rev'd, 244 F.3d 572 (7th Cir.), cert. denied, 534 U.S. 994 (2001).

27. Am. Amusement Mach. I, 115 F. Supp. $2 \mathrm{~d}$ at 946 (citations omitted). The ordinance also defined "strong sexual content" to include "nudity or explicit human sexual behavior by any human or human-like being in one or more of the following forms: masturbation; deviate sexual conduct; sexual intercourse; or, fondling of genitals." Id. at 947 (citations omitted).

28. For the ordinance, see Interactive Digital Software Ass'n v. St. Louis County, 200 F. Supp. 2d 1126 (E.D. Mo. 2002). 
violent video game play in arcades. ${ }^{29}$ The Mississippi State Senate also considered a bill that would have limited sale, rental, or arcade play, ${ }^{30}$ as did the House of the Georgia General Assembly. ${ }^{31}$ In Connecticut, a similar bill, addressing arcade play by those under eighteen passed through the legislature ${ }^{32}$ but failed to gain the governor's support. In Oklahoma, a similar bill passed in the senate, but the house refused to consider the bill ${ }^{33}$ and eventually a weaker bill amended existing law addressing the distribution to minors of material with strong sexual content to include video games containing sadomasochistic depictions. ${ }^{34}$

The issue of the exposure of children to violent video games has also recently attracted congressional attention. Representative Joe Baca, with twenty-one cosponsors, introduced a bill titled the Protect Children from Video Game Sex and Violence Act of 2002. ${ }^{35}$ The bill would have prohibited the sale or rental to a minor, defined as seventeen and younger, of any video game depicting:

(1) decapitation, amputation, dismemberment, or mutilation;

(2) the killing of human beings or human-like beings by the use of an object as a lethal weapon or hand-to-hand fighting;

(3) the car jacking of a vehicle;

(4) the use of illegal drugs;

(5) rape or other sexual assault;

(6) prostitution;

(7) aggravated assault or battery; or

(8) any other violent felony. ${ }^{36}$

29. See Lisa Grace Lednicer, Bill Would Zap Teen Use of Violent Games, THE OREGONIAN, Feb. 20, 2001, at A1, available at 2001 WL 3586962.

30. See S. 2048, Reg. Sess. (Miss. 2000), 2002 WL 4897987.

31. See H.R. 1378, 146th Gen. Assem., Reg. Sess. (Ga. 2001), 2001 GA H.B. 1378.

32. See Carrie Budoff, Lawmakers Take Aim at Video Games: Rowland's Approval Needed On Bill Targeting Violent Images, HARTFORD COURANT, May 17, 2001, at Al.

33. See Brian Ford, Violent-Video Bills Appear Dead, TULSA WORLD, Apr. 1, 2001, at 17.

34. See OKLA. Stat. ANN. tit. $21, \S 1040.75$ (West Supp. 2001).

35. See H.R. 4645, 107th Cong. (2002).

36. Id. 
The efforts to limit exposure to violent video games have met with only limited success in the courts. The Indianapolis and St. Louis County ordinances were quickly challenged by the video games industry. In both cases, federal district courts refused to enjoin the enforcement of the ordinances. The Indianapolis ordinance was, however, not as well received by the United States Court of Appeals for the Seventh Circuit, which ordered that an injunction be entered.

The Indianapolis district court case was styled American Amusement Machine Ass' $n$ v. Kendrick. ${ }^{37}$ The video game industry had requested an injunction against the enforcement of the ordinance on the grounds that it violated the First Amendment. The court accepted the position that at least some video games enjoy the protection of the amendment, but concluded that the plaintiffs were unlikely to be able to show that the ordinance was unconstitutional. The ordinance did not limit the access of adults to the games at issue and the scope of children's right to access is more limited than adult rights. The court relied on the Supreme Court's decision in Ginsberg v. New York ${ }^{38}$ holding that sexual material not obscene for an adult audience can be considered obscene when distributed to minors. Application of the case requires the equation of sexual material and depictions of violence, but the court was willing to take that step, stating "the court is not persuaded there is any principled constitutional difference between sexually explicit material and graphic violence, at least when it comes to providing such material to children." ${ }^{39}$ That conclusion that violence can be subsumed under the variable obscenity standard of Ginsberg, coupled with what the court recognized as strong interests in limiting the harmful effects of violent video games on children, justified the ordinance.

The district court decision was appealed to the United States Court of Appeals for the Seventh Circuit, and the industry fared far better there. An opinion by Judge Posner rejected the inclusion of depictions of violence within the category of the obscene, concluding that the two are "distinct categories of objectionable depiction." is limited because the community finds it offensive, while Indianapolis was motivated by a concern that violent video games cause aggressive real world behavior. ${ }^{41}$ It is far from clear, however, that those who object to sexually

37. 115 F. Supp. 2d 943 (S.D. Ind. 2000), rev'd, 244 F.3d 572 (7th Cir.), cert. denied, 534 U.S. 994 (2001).

38. 390 U.S. 629 (1968).

39. Am. Amusement Mach. I, 115 F. Supp. 2d at 946.

40. Am. Amusement Mach. Ass'n v. Kendrick, 244 F.3d 572, 574 (7th Cir.) [hereinafter Am. Amusement Mach. II], cert. denied, 534 U.S. 994 (2001) (citations omitted).

41. See Am. Amusement Mach. II, 244 F.3d at 574. 
obscene materials do so solely out of a sense of being offended. Concerns, especially regarding the provision of such material to youth, can just as well focus on a concern that the children seeing the material will engage in sexual activity inappropriate for their age. Neither is it clear that the members of a community such as Indianapolis cannot feel offended by the exposure of children to media violence.

Since the appellate court concluded that the games, even those with strong violent content, are protected, the ordinance had to stand up to strict scrutiny; the ordinance had to address a compelling governmental interest and be narrowly tailored to that interest. ${ }^{42}$ Indianapolis's interest was in preventing real world youth violence resulting from playing violent video games. Judge Posner rejected the link between video games and the real world, concluding that the social science evidence did not support the ordinance. ${ }^{43}$ Violence is found in other contexts and there was no justification for singling video games out from a background of violent images for special treatment. "The studies do not find that video games have ever caused anyone to commit a violent act, as opposed to feeling aggressive, or have caused the average level of violence to increase anywhere." ${ }^{44}$ The court seemed to assume that the access of children to violent films could not be restricted and concluded that there was no justification, including the interactive nature of video games, to distinguish the games from such other media. ${ }^{45}$ Despite a great deal of empirical evidence supporting the concern that exposure of children to images of violence makes the world a more violent place and the conclusions of major health organizations that media violence plays a causative role in real world violence, ${ }^{46}$ Judge Posner concluded that "[c]ommon sense says that the City's claim of harm to its citizens from these games is implausible, at best wildly speculative." 47

The St. Louis County ordinance also fared well at the federal district court level. There, too, the video game industry sought an injunction against the enforcement of the ordinance, and the court refused the request. The court, in Interactive Digital Software Ass' $n v$. St. Louis County ${ }^{48}$ examined three theories under which the ordinance would be valid. The court rejected

42. See id. at 576.

43. See id.

44. Id. at $578-79$.

45. See id. at 579.

46. That evidence is discussed infra notes 57-98 and accompanying text, and the statement of the health organizations is presented infra note 87 and accompanying text.

47. Am. Amusement Mach. II, 244 F.3d at 579.

48. 200 F. Supp. 2d 1126 (E.D. Mo. 2002). An appeal has been filed with the United States Court of Appeals for the Eighth Circuit. See Interactive Digital Software Ass'n v. St. Louis County, No. 02-3010 (8th Cir. filed Sept. 18, 2002). 
the county's claim that violence could be considered obscene, at least when made available to minors, since it saw that theory as having been rejected for video tapes by the federal appellate court of its circuit in Video Software Dealers Ass' $n v$. Webster. ${ }^{49}$ With regard to the harm such games can cause, the court was greatly at odds with Judge Posner's view. ${ }^{50}$ While Judge Posner may have seen such claims as implausible, in Judge Limbaugh's view "[f]or plaintiffs to ... argue that violent video games are not harmful to minors is simply incredulous." ${ }^{1}$ In the St. Louis court's view, the county had a compelling interest in protecting minors from that harm and the ordinance was narrowly tailored to that interest, since it affected only those potential players who are under seventeen and who have not obtained their parents' permission to play. ${ }^{52}$

The most interesting aspect of the St. Louis opinion, however, was its conclusion that video games simply do not enjoy the protections of the First Amendment. ${ }^{53}$ Video games do not involve communication necessary for the Constitution's free expression guarantees to apply. Rather than having the protection of entertainment forms such as motion pictures, video games were said to be more akin to board games or bingo. ${ }^{54}$ Games such as bingo, blackjack, and baseball are not forms of expression, and none of them become forms of expression simply because the action occurs through buttons and joy sticks, rather than cards and wooden or aluminum bats. Without the protection of the First Amendment, the ordinance could clearly stand up to the rationality requirements of laws that do not infringe on the constitutional rights of the individual.

Since the Indianapolis and St. Louis ordinances are likely to be just the first of many to come and since each new effort will likely lead to litigation, the arguments raised in the cases discussed merit consideration. The three theories potentially justifying video game restrictions will be discussed in turn, beginning with the theory that requires the least contraction of first amendment theory. That theory turns on the violence inducing effects of violent video games. If the interest in protecting children is compelling and the danger is real, an ordinance narrowly addressed to that issue is constitutional under generally applicable constitutional doctrine. The second approach to be addressed will be the theory that depictions of violence can come within an existing exception to first amendment protection, the

49. 968 F.2d 684 (8th Cir. 1992).

50. See Video Software Dealers Ass'n v. Webster, 968 F.2d 684, 686 (8th Cir. 1992).

51. Interactive Digital Software, 200 F. Supp. 2d at 1138.

52. See id.

53. See id.

54. See id. 
obscenity exception. If violence can be obscene, then the degree of violence present in some video games could come within a violence application of the variable obscenity standard employed when materials are made available to children. That is, even if adults should be allowed to play, children can be restricted. Lastly, the position that video games are not expression and do not enjoy first amendment protection will be examined. The position taken here will be that each of the three arguments is valid, that is, that any of the three justifications suffices to justify restricting the access of minors to violent video games. The last section of the article will address the drafting of statutes imposing restrictions and how the justification adopted affects the structure of the statute or ordinance.

\section{Video Games AND REAL World VIOLENCE - MEeTING STRICT SCRUTINY}

The issue of whether or not violent video games cause real world violence is important because the conclusion that there is causation could justify restrictions on video game access, even if the games have the full protection of the First Amendment. The Webster court did strike down a limitation on distributing violent videos to minors and found that violent materials are protected by the First Amendment, but the court did not conclude that such materials are absolutely protected. The enjoyment of the protections of the expression clauses requires only that the limitation be judged against the strict scrutiny standard. It must be narrowly tailored to promote a compelling governmental interest. The court there was willing to recognize a compelling interest in protecting the physical and psychological well-being of minors but concluded that the statute was not narrowly drawn to serve that interest. ${ }^{55}$ The statute failed to state with particularity the types of violence that the legislature determined to be detrimental to minors, so the court could not determine if the statute was narrowly drawn to ban only that expression. ${ }^{56}$ If violent video games do not cause real world violence, as Judge Posner indicated, then a compelling interest may well be lacking. Even if they do cause such violence, Webster cautions that any restrictive legislation must be drafted so to focus narrowly on the video games that contribute to the danger.

55. See Video Software Dealers Ass'n v. Webster, 968 F.2d 684, 686 (8th Cir. 1992).

56. See Video Software Dealers Ass'n, 968 F.2d at 686. 


\section{A. Research on the Effects of Violence in Other Media}

Violent video games are a relatively recent phenomenon, and the research on the effects of violent video games is only beginning to develop. There is, however, a great body of social science literature on the effects of television and film violence. There may be differences between the effects on passive exposure to violence in the media that one simply watches and the more active role of the video game player. Nonetheless, the video game player is also a watcher of the action. Whatever effects such passive exposure have should also be present in video games, with perhaps additional effects as well. The studies on the passive media are then relevant to the issue of the effect of violent video games on real world violence. With the passive media there is a large body of social science research that supports the contention that media violence in general causes violence in the real world.

The science regarding the effects of film and television falls into three categories; laboratory studies, field studies, and correlation studies. ${ }^{57}$ Laboratory studies consist of observations of individuals in a controlled environment and constituted the early research on the effects of media violence. Professor Bandura directed what has become the classic study.$^{58} \mathrm{He}$ worked with a group of nursery school children given the opportunity to play with an inflated five foot Bobo doll, a doll that stands back up when knocked over. Before playing with the doll, different groups of children saw an adult hitting and kicking it, a film of the same acts, or a film of the same actions made to appear as a cartoon. There was also a control group not exposed to the actual or filmed play with the doll. The children were then frustrated or mildly angered by showing them some toys and telling them that they could not play with those toys because they were being saved for other children. They were then allowed to play with a different group of toys, both nonaggressive toys and aggressive toys, including a Bobo doll. The researchers rated the levels of aggression shown by the children in their play with the toys. The three experimental groups were significantly more aggressive, almost twice the level of aggression, compared to the control group. ${ }^{59}$

This media induction of aggression is not limited to preschool age children. Male university students were the subjects of a series of studies led

57. For a more detailed discussion of the social science see KEVIN W. SAUNDERS, Violence as OBSCENITY: Limiting the MEdiA's First AMENDMENT ProteCtion 29-44 (1996).

58. See Albert Bandura et al., Imitation of Film-Mediated Aggressive Models, $66 \mathrm{~J}$. ABNORMAL \& SOC. PSYCHOL. 3 (1963).

59. See id. 
by Professor Leonard Berkowitz. ${ }^{60}$ His studies also examined the effect of meaning and context. Groups of students were shown one of three films and the context of the action in each of the violent films in the studies was explained in two ways. Two groups of students saw an excerpt from the film Champion in which a character played by Kirk Douglas is badly beaten in a boxing match. One of those groups was told that the film involved two professional prize fighters simply fighting for a purse. The other was told Douglas' opponent was angry and wanted to injure him. A second film involved a football game, with one group told it was just a professional contest and another told that one team had a particular reason to want to beat the other. The last group was a control group shown what was described as an exciting film of a track race. ${ }^{61}$ Before they saw the films, the subjects were given reason to be somewhat angry toward an assigned partner said to be another subject of the study but actually a part of the research team. After the film, they were told to rate the ideas offered by their partners by administering electric shocks. The groups that had seen the "aggressive meaning" film administered significantly more shocks and shocks of longer duration.

These studies, and others like them, can and have been criticized. ${ }^{62}$ The most serious question is over whether or not laboratory results carry over to the real world. The children in the Bobo doll experiment may have taken the acts they had seen as instruction on how to play with that particular toy or at least as providing permission to do what they had seen adults do. Of course, if the same is said of media violence it does not defeat claims of causation, since the media would be seen as showing that violent acts are acceptable and as providing instruction on social interaction. For video games, as discussed below, the instructive aspects may be particularly strong. It may also be argued that the laboratory studies really measure compliance with the investigator, rather than induced aggression..$^{63}$ That, however, would require awareness of the behavior the researcher desired, and Berkowitz controlled for

60. See Leonard Berkowitz \& Joseph T. Alioto, The Meaning of an Observed Event as a Determinant of Its Aggressive Consequences, 28 J. PERSONALITY \& SOC. PSYCHOL. 206 (1973).

61. The study refers to this film as "our standard 6-minute movie of a track race." Id. at 209. It appears to be of a race between the first two runners to break the four minute mile. Berkowitz used that film in other studies. See, e.g., Leonard Berkowitz \& Russell G. Geen, Film Violence and the Cue Properties of Available Targets, 3 J. PERSONALITY \& SOC. PSYCHOL. 525,527 (1966).

62. See, e.g., Marcia Pally, Sex \& Sensibility: Reflections on Forbidden MirRoRS AND THE WILl TO CENSOR 28-29, 88-93 (1994).

63. See id. at 93. 
this by including as a factor in the results awareness of the purpose of the study. ${ }^{64}$

Field studies may be less subject to the criticism that the results do not carry over to the real world, because they involve real world settings. On the other hand, because they occur outside the laboratory, they are not as amenable to the controls available there. Because of this lack of controls and because the settings seem somewhat artificial, there is disagreement over the conclusions to be drawn. A Belgian study presents an example of that disagreement. Two groups of institutionalized boys were shown either violent or nonviolent films for a period of one week. The aggressiveness of the members of the groups was then rated ${ }^{65}$ Looking at the results, Professor Jonathan Freedman, ${ }^{66}$ a skeptic regarding television's causative role in violence, and Professors Lynette Friedrich-Cofer and Aletha Huston, ${ }^{67}$ who seem to accept such effects, came to very different conclusions. According to Friedrich-Cofer and Huston:

In the Belgian study, physical aggression increased significantly . . . in both cottages assigned to violent films, but did not increase in the neutral film cottages. Total aggression, including both physical and verbal aggression, increased primarily in the violent film cottage that was initially more aggressive. In two U.S. studies total aggression was significantly higher in two cottages viewing television violence for 5 days than in cottages viewing neutral films. ${ }^{68}$

Freedman, however, finds only "some evidence to support the causal hypothesis."

[I]t does seem that [one of the experiments] found a consistent increase in aggressiveness for one cottage and a short-term increase on one measure for the other, and [a second] study found a greater increase in aggressiveness after violent films than after nonviolent films. The interpretation of the results of [a third] study depends on which analysis one accepts. At most, there is rather weak evidence for a greater

64. See Berkowitz \& Alioto, supra note 60, at 210-11.

65. For the studies examined see Jacques-Philippe Leyens et al., Effects of Movie Violence on Aggression in a Field Setting as a Function of Group Dominance and Cohesion, 32 J. PERSONALITY \& SOC. PSYCHOL. 346 (1975); Ross D. Parke et al., Some Effects of Violent and Nonviolent Movies on the Behavior of Juvenile Delinquents, in 10 ADVANCES IN EXPERIMENTAL SOCIAL PSYCHOLOGY 135 (Leonard Berkowitz ed., 1977).

66. See Jonathan L. Freedman, Effect of Television Violence on Aggressiveness, 96 PSYCHOL. BULL. 227 (1984).

67. See Lynette Friedrich-Cofer \& Aletha C. Huston, Television Violence and Aggression: The Debate Continues, 100 PsYCHOL. BULL. 364 (1986). Professors FriedrichCofer and Huston's article is written in part as a response to Professor Freedman.

68. Id. at 365 .

69. Freedman, supra note 66 , at 231. 
increase in aggressiveness following violent films; at worst, there are no main effects, but perhaps a differential increase for low-aggressive boys only. ${ }^{70}$

He questions even these results, because the study treated the subjects as independent of each other, while aggression on the part of one of the boys may have been the real cause of aggression in others.

Addressing the totality of field studies, Freedman says there is "only the slightest encouragement for the causal hypothesis" and he finds even that slightest support to be questionable. ${ }^{71}$ Friedrich-Cofer and Huston, in contrast, conclude that there is "a moderately consistent pattern suggesting an effect of television violence on aggression and self-control, particularly for subjects with relatively high baseline levels of aggression."72 They even suggest that there may be an underestimation of the causal effects of television violence in the field studies, because of the inhibiting presence of the adult experimenters. ${ }^{73}$

The last variety of the older social science experiments is the correlational study, a real world study of populations examining relations between demographic variables, either looking at different populations at one point in time or the same population over an extended period. One of the first such studies in the area was Dr. Brandon Centerwall's examination of the introduction of television and the homicide rate in which he found a correlation between the increase in televisions and a ten to fifteen year later rise in the homicide rate. ${ }^{74}$ In both the United States and Canada the curve representing increased numbers of televisions in the 1950s was roughly parallel to the curve representing increased homicide rates in the late $1960 \mathrm{~s}^{75}$ South Africa did not show the same increase in the late 1960s, and it is interesting to note that television was not available there until the 1970s.

Similar results were obtained in an even earlier study of a small, isolated Canadian town that had no television until $1973 .^{76}$ Groups of first and second graders there and in two other towns that were similar, except in that television was already present, were observed over a two year period. In the

70. Id.

71. Id. at 234.

72. Friedrich-Cofer \& Huston, supra note 67, at 366.

73. See id.

74. See Brandon S. Centerwall, Television and Violence: The Scale of the Problem and Where to Go From Here, 267 JAMA 3059 (1992).

75. See id. Centerwall suggested that the delay was because homicide is an adult behavior and television's effect on children would require a ten to fifteen year incubation period. See id.

76. See Lesley A. Joy et al., Television and Children's Aggressive Behavior, in THE IMPACT OF TELEVISION: A NATURAL EXPERIMENT IN THREE COMMUNITIES 303 (Tannis MacBeth Williams ed., 1986). 
towns that had already had television there were no significant behavioral changes, but in the town new to television, there was a significant increase in physical aggression on the part of the town's children.

Demographic studies also have their problems, centering on the difficulty of controlling variables in the real world and on the sheer number of variables present, especially in studies that occur over an extended period of time. That possibility of the effects of uncontrolled variables lessens the surety with which results can be accepted. As an example, in Dr. Centerwall's study the increase in televisions was not the only relevant change in the time period studied. The increase in the homicide rate occurred in the years in which the baby boom population passed through their teens and early twenties, the ages when a person is most likely to be violent. ${ }^{77}$ Marcia Pally also points to a problem comparing the United States and Canadian results with South Africa. ${ }^{78}$ South Africa saw very strong governmental control in the 1970s and, she suggests, a siege mentality among South African whites and a better economy in the relevant years may explain the differences. Pally also raises questions over the study of the introduction of television to the isolated Canadian town, since Canadian television was not very violent at the time. ${ }^{79}$

An example of a long term demographic study is found in the work of Doctors Lefkowitz, Eron, Walder, and Huesmann. ${ }^{80}$ Their study began in 1955 by examining all the third graders in Columbia County, New York, using data from the children's parents and classmates and the children themselves. The children were rated for aggressiveness, based on classmate assessments of disobedience to the teacher, fighting, taking things from others, and other similar acts. The experimenters also interviewed parents to find the children's television viewing habits and to gain input on some forty other variables concerning personality, intelligence, social status, and family situation. The same students were studied when in the eighth grade and after high school graduation. The results showed that watching violent television in the third grade was correlated, to a statistically significant degree, to aggressiveness in the third grade and even more significantly to aggressiveness after high school.

77. This point is made by Marcia Pally in her criticism of the social science on television causing aggression. See PALLY, supra note 62, at 108-09.

78. See id. at 109.

79. See id. at 112.

80. See Monroe M. Lefkowitz et al., Television Violence and Child Aggression: $A$ Followup Study, in TELEVISION AND SOCIAL BEHAVIOR: REPORTS AND PAPERS, Vol. III: TELEVISION AND ADOLESCENT AGGRESSIVENESS 35 (George A. Comstock \& Eli A. Rubinstein eds., 1972). 
Once again, the study is not beyond criticism. It may be that those who are disposed toward aggression also choose to watch violent television and that the television violence then did not cause aggression. The study, however, concluded that violent television causes aggression, because there was no correlation found between aggressiveness in third grade and later watching of violent television. ${ }^{81}$ There is also valid criticism of the grouping of the television programs considered violent. Gun Smoke or The Man from U.N.C.L.E. are certainly reasonably considered violent television shows, but the inclusion of the slapstick of the Three Stooges or the comedy of Get Smart may have made the category overly broad. ${ }^{82}$ Furthermore, cartoons and soap operas were classified as nonviolent, but cartoons have long faced criticism for their violence. It is worth noting that this criticism is directed only at causal claims. The correlational studies do establish at least a correlation between television violence and aggressive behavior, as recognized even by causal skeptics such as Freedman. ${ }^{83}$

Any single study may be criticized, and each variety of study has its weaknesses, but the body of research taken as a whole provides a strong basis for the conclusion that media violence causes violence in the real world. That strength is demonstrated through meta-analysis, which applies quantitative techniques to examine all the studies in the scholarly literature and provides an objective synthesis of that research. If an analysis shows that the results are consistent from study to study and from method to method, the conclusion is certainly greatly strengthened. In the early 1990s, Professors Comstock and Paik examined almost two hundred methodologically sound studies, both published and unpublished, studying the relationship between television

81. See id. at 49. The statistical methods used in arriving at this conclusion were questioned by Professor David Kenny. He did, however, also conclude that the data, using what he took to be the proper approach, did demonstrate the conclusion that violent television causes aggression, but with a lesser degree of statistical significance. See David A. Kenny, Threats to the Internal Validity of Cross-Lagged Panel Inference, as Related to "Television Violence and Child Aggression: A Followup Study", in TELEVISION AND SOCIAL BEHAVIOR: REPORTS AND PAPERS, VOL. III: TELEVISION AND ADOLESCENT AGgRESSIVENESS 136 (George A. Comstock \& Eli A. Rubinstein eds., 1972). Professor John Neale, using still different techniques, also found support for the original conclusion. See John M. Neale, Comment on "Television Violence and Child Aggression: A Followup Study", in TELEVISION AND SOCIAL BEHAVIOR: REPORTS AND PAPERS, VOL. III: TELEVISION AND ADOLESCENT AGGRESSIVESNESS 141 (George A. Comstock \& Eli A. Rubinstein eds., 1972).

82. This argument is similar to that made by Professor William McGuire, who expresses concern that a murder scores no higher as an incidence of violence than pushing or restraining a person, slapstick comic violence, and cartoon conflicts. See William J. McGuire, The Myth of Massive Media Impact: Savagings and Salvagings, in 1 PUBLIC COMMUNICATION AND BEHAVIOR 173, 191 (George Comstock ed., 1986).

83. See Freedman, supra note 66, at 243. 
violence and aggressive behavior. ${ }^{84}$ Based on their meta-analysis, the authors concluded that the studies, in the aggregate, show that television violence increases aggressive behavior of all types, including criminal behavior. ${ }^{85}$

Even meta-analysis may be criticized, and the relevance of the conclusions drawn by Comstock and Paik has been questioned. ${ }^{86}$ The criticism was not of the analysis employed but concerned the size of the effect that can be demonstrated. Even accepting the statistical significance of the relationship between viewing violence and aggressive behavior, if the contribution of television to aggression is small, then the effect of television may be seen as not being worth addressing. The response to this criticism is that even a small increase in aggression may push those most prone to violence actually to commit violent acts or even homicide.

Despite shortcomings in any given experiment, the aggregate of social science and psychological research clearly demonstrates a connection between media violence generally and real world violence. That is not to claim that every child who watches television or plays violent video games will go out and commit violence, but neither will every person who smokes develop lung cancer. Nonetheless, six major professional organizations in the health field found the science conclusive. In a joint statement, issued in July 2000, the American Psychological Association, the American Academy of Pediatrics, the American Academy of Child and Adolescent Psychiatry, the American Medical Association, the American Academy of Family Physicians, and the American Psychiatric Association concluded that "well over 1000 studies . . . point overwhelmingly to a causal connection between media violence and aggressive behavior in some children." 87

The American Academy of Pediatrics had in an earlier policy statement said that " $[t]$ he vast majority of studies conclude that there is a cause-andeffect relationship between media violence and real-life violence." the link "undeniable and uncontestable." ${ }^{\text {A }}$ A representative of the same pediatrics group, in the year 2000, testified before the United States Senate Commerce Committee that there are now more than 3,500 studies examining the relationship between media and real world violence and that "[a]1l but 18

84. See Haejung Paik \& George Comstock, The Effects of Television Violence on Antisocial Behavior: A Meta-Analysis, 21 COMM. RES. 516 (1994).

85. See id.

86. See PALLY, supra note 62, at 93-97.

87. American Academy of Pediatrics, Joint Statement on the Impact of Entertainment Violence on Children: Congressional Public Health Summit para. 4 (July 26, 2000), available at http://www.aap.org/advocacy/releases/jstmtevc.htm.

88. American Academy of Pediatrics, Committee on Communications, Media Violence, 95 PEDIATRICS 949, 949 (1995).

89. Id. 
have shown a positive correlation between media exposure and violent behavior" and that epidemiological studies conclude that "exposure to violent media was a factor in half of the 10,000 homicides committed in the United States in [the year studied.]"90

The view of the scientific community seems to be that the debate is over and that it is clear that there is a connection between media violence and aggression in the real world. The Surgeon General's report, Youth Violence, noted that ethical considerations bar the use of the sort of randomized studies that are best used to determine causation. Nonetheless, the report reaches the conclusion that "a diverse body of research provides strong evidence that exposure to violence in the media can increase children's aggressive behavior in the short term." W1 While less secure in concluding that there is a causal connection to violence in the long term, the report does find a "small but statistically significant impact on aggression over many years." 92 Again, remember that that conclusion was based on the passive media, and the active engagement in virtual violence in video games would seem likely to have an even greater effect. ${ }^{93}$

Given the evidence on the causal effects of media violence, the disjoint between science and what seems to be the perception of at least a portion of the public that there is no causation seems puzzling. It is not surprising that the media continues to deny any causation. Media executives will, like tobacco executives for lung cancer, be the last to admit such a connection. The difference between the effectiveness of the denials on the part of the two industries may be that the media industry also controls the outlets through which the public gains the information necessary to form its views. A recent study, published in the American Psychological Association's journal American Psychologist, finds a "disheartening" discrepancy between science and media reporting. "As it became clearer to the scientific community that media violence effects were real and significant, the news media reports actually got weaker." ${ }^{95}$ The authors report instances in which Newsweek and

90. Testimony of the American Academy of Pediatrics on Media Violence before the U.S. Senate Commerce Committee para. 4 (September 13, 2000) (statement of Donald E. Cook, M.D., President, American Academy of Pediatrics), at http://commerce.senate.gov/ hearings/0913coo.pdf.

91. Youth Violence: A Report to the Surgeon General para. 4 app. 4-B, at http://www.surgeongeneral.gov/library/youthviolence/chapter4/appendix $4 \mathrm{bsec} 3 . \mathrm{html}$ (last visited Mar. 12, 2003).

92. Id. at para. 1.

93. See infra notes 99-121 and accompanying text.

94. See Brad J. Bushman \& Craig A. Anderson, Media Violence and the American Public: Scientific Facts Versus Media Misinformation, 56 AM. PsYCHOL. 477, 485 (2001).

95. Id. 
The New York Times published articles or op-eds claiming that there was no causative evidence and then would not publish replies from the scientific community. ${ }^{96}$

It can, of course, be claimed that all the scientific evidence is able to show is correlation rather than causation. That may seem like a reasonable argument, but it does not really weaken the scientific conclusion. As empiricists since David Hume note, one can never observe causation but only a form of correlation Hume called constant conjunction. ${ }^{97}$ The constancy of that conjunction, the perfect correlation, may make one more secure in drawing the causal conclusion, but there is a jump from observation to conclusion. That jump may be less justified when the conjunction is not constant, but it is one the scientific community makes with regularity. There is only an imperfect correlation between smoking and lung cancer, between unprotected sex and AIDS, and between low calcium intake and osteoporosis. That is, not everyone who smokes gets lung cancer and some who get lung cancer did not smoke, and the same is true for the other relations involving AIDS and osteoporosis. Yet, those relations are seen confidently as causal.

The failure to accept the correlation as causation in the case of media violence is not due to the degree of correlation. The correlation between media violence and aggression is stronger than that of failure to use a condom and HIV, second hand smoke and lung cancer, lead exposure in children and lower IQs, use of the nicotine patch and smoking cessation, calcium intake and bone mass, homework and academic achievement, asbestos exposure and cancer of the larynx, and self-examination and early detection of breast cancer. ${ }^{98}$ While the correlation between smoking and lung cancer is more significant than that between media violence and aggression, the acceptance of all these lesser correlations as indicating causation lead to the conclusion that the correlation in the case of the media ought also to be considered sufficient to allow society to proceed on the assumption that there is causation.

One last objection that might be made has to do with the mechanism of causation. Perhaps there is a greater willingness to conclude that there is causation in the case of second hand smoke or lack of condom use because the mechanisms bringing about the results are more easily understood. The brain is, to most if not all of us, mysterious, but so is the rest of science, if the analysis is sufficiently deep. It is clear to all that gravity causes objects to fall to the earth, but try explaining, even to yourself, why it is that objects with

96. See id. at 486.

97. See David Hume, A TREatise Of Human Nature 86-94 (L. A. Selby-Bigge ed., Oxford 1964) (1888).

98. See Bushman \& Anderson, supra note 94, at 481 . 
mass attract each other. Most of us, having experienced even mild visceral effects from viewing violence, would have a better understanding of how that exposure might lead some to have a sufficiently strong response as to lead to violence or to experience a sufficiently long lasting effect as to be more aggressive in the future.

\section{B. Causation and Video Games}

Moving from the passive media such as television and film to the active participation of video games, it would seem reasonable to expect an increase in the causative effect of that variety of media violence. The interactivity of the violent video game in which the player himself responds using virtual violence would seem more likely to lead the player to respond with violence in future situations than would simply viewing characters on a screen. Judge Posner, however, called that distinction "superficial."

Maybe video games are different. They are, after all, interactive. But this point is superficial, in fact erroneous. All literature (here broadly defined to include movies, television, and the other photographic media, and popular as well as highbrow literature) is interactive; the better it is, the more interactive. Literature when it is successful draws the reader into the story, makes him identify with the characters, invites him to judge them and quarrel with them, to experience their joys and sufferings as the reader's own. ${ }^{99}$

But rather than that distinction being superficial, Posner's response is an equivocation, an argument that relies on two different uses of a word. To say that literature is interactive because the reader empathizes with a character is a far cry from interactivity in the sense of participation in the action. It is the difference between being a member of the audience at a play and being part of the cast of that play. The actor interacts with the others in the cast, and that is different from any empathy the audience may feel. The interactivity of a flight simulator is a qualitatively different experience, and one more likely to lead to a response in actual flight, than reading a flight manual, watching one

99. Am. Amusement Mach. Ass'n v. Kendrick, 244 F.3d 572, 577 (7th Cir.) [hereinafter Am. Amusement Mach. II], cert. denied, 534 U.S. 994 (2001). 
of the Airport movies, or reading the most engaging descriptions penned by pilots. ${ }^{100}$

The research on the effects of violent video games has not developed to the point where it matches that on the effects of film or television. Video games, and in particular the violent, first person shooter games in a realistic graphics environment, are simply too new a medium to match the extensive research on the older media. There would, however, appear to be nothing about those other media that would prevent the export of their conclusions to video games, and there are at least speculative reasons, based on interactivity, to suggest that the causative results would be even stronger.

While not as fully developed, ${ }^{101}$ research on the modern variety of video games has begun. Professors Craig Anderson and Karen Dill recently published the first scientific comparison of the aggressiveness producing effects of violent and nonviolent video games, ${ }^{102}$ and the results are similar to studies comparing violent and nonviolent television or film. Their effort proceeded on two fronts, one a correlational/demographic variable study and the other a laboratory experiment. In the correlational study they examined 227 university students. The students were questioned both on their total exposure to video games and their specific exposure to violent video games in the present, eleventh and twelfth grade, ninth and tenth grade, and seventh

100. Even accepting Judge Posner's point as to the interactivity of good literature or film, the argument that violent video games are particularly dangerous still holds. Even if the experience is not qualitatively different, the quantitative difference in identification through participation may make the experience more likely to produce aggression. Studies have shown that subjects who identify with a media aggressor are more likely to become aggressive than subjects not so inclined. See, e.g., Craig A. Anderson \& Karen E. Dill, Video Games and Aggressive Thoughts, Feelings, and Behavior in the Laboratory and in Life, $78 \mathrm{~J}$. PERSONALITY \& SOC. PSYCHOL. 772 (2000) (citing Jacques-Philippe Leyens \& Steve Picus, Identification with the Winner of a Fight and Name Mediation: Their Differential Effects upon Subsequent Aggressive Behaviour, 12 BRIT. J. SOC. \& CLINICAL PSYCHOL. 374 (1973)).

101. There is earlier research on the effects of violent video games, but the rapid evolution of the games in their capacity to convey realistic depictions of deadly violence against persons makes the older studies less relevant. For example, a study of children playing Activision Boxing compared to others playing Atari Boxing, see Daniel Graybill et al., Effects of Playing Violent Versus Nonviolent Video Games on the Aggressive Ideation of Aggressive and Nonaggressive Children, 15 CHILD STUDY J. 199 (1985), or comparing those playing PacMan with those playing Missle Command, see Joel Cooper \& Diane Mackie, Video Games and Aggression in Children, 16 J. APPLIED SOC. PsYCHOL. 726 (1986), cannot measure the effects of clearly more violent and more realistic modern games. These earlier games are simply not as violent, and as the authors of the latter study indicate, the children may not really see any significant difference in level of violence between Pac-Man eating or being eaten by ghosts and Missle Command's shooting down of invading alien space ships. See Cooper \& Mackie, supra, at $740-41$.

102. See Anderson \& Dill, supra note 100. 
and eighth grades. A number of instruments were also administered to measure their irritability, physical and verbal aggression, anger, hostility and history of delinquent acts. Anderson and Dill's analysis of the data led them to conclude that violent video game play was more strongly correlated with delinquency than nonviolent video game play and that "concern about the deleterious effects of violent video games on delinquent behavior, aggressive and nonaggressive, is legitimate. Playing violent video games often may well cause increases in delinquent behaviors, both aggressive and nonaggressive." 103 They were, however, reluctant to draw a conclusion as to causation from a correlational study. ${ }^{104}$

The second laboratory study involved the video game Wolfenstein $3 D$. The game is described in the study as having "blatant violent content, realism, and human characters." 105

[T] he human hero can choose from an array of weaponry including a revolver, a knife, automatic weapons, and a flame thrower. The hero's goal is to use these weapons to kill Nazi guards in Castle Wolfenstein to advance through a number of levels; the ultimate goal is to kill Adolph Hitler. The graphics . . . are very violent; a successful player will see multiple bloody murders and hear victims scream and groan. ... [T] he 3D setting is realistic. ${ }^{106}$

While a pilot study considered two other nonviolent video games, Myst and Tetris, as controls, Myst was used in the actual study because of its match with Wolfenstein $3 D$ with regard to the similar blood pressure and heart rates of players playing the two games and similar difficulty, enjoyment, frustration, and action levels of the two games. ${ }^{107}$

The study involved 210 university students selected on the basis of an earlier administered irritability scale. From that instrument, the top quarter and bottom quarter were invited to participate, resulting in a pool of low and high irritability subjects. The students were then grouped into four populations: high irritability males, high irritability females, low irritability males, and low irritability females. Each of these groups was split into two groups, one playing Wolfenstein $3 D$ and the other playing Myst. Each person played the assigned game three times, with differing psychological instruments administered after the first two games. After the third game, the subjects were told that they would participate in a competitive reaction time

103. Id. at 782 .

104. See id.

105. Id. at 783 .

106. Id.

107. See id. Male players did report that they found Wolfenstein $3 D$ more exciting then Myst, despite the similar physical responses; the view was not shared by female subjects. See Anderson \& Dill, supra note 100, at 786. 
task in which they tried to push a button faster than their opponents. The game was controlled so that the participant subjects all won thirteen of the twenty-five trials. When they lost, they were subjected to a blast of noise at a level said to be set by the opponent but actually controlled by the experimenters. Each subject, prior to each trial, set the duration and intensity of the noise blast his or her opponent would hear, if the participant won the trial. After each trial, the participant was shown the noise level said to have been selected by the opponent. The results showed that "participants who had played Wolfenstein 3D delivered significantly longer noise blasts after lose trials than those who had played the nonviolent game Myst. . . . In other words, playing a violent video game increased the aggressiveness of participants after they had been provoked by their opponent's noise blast." 108

Anderson and Dill conclude that the combination of correlational and laboratory results support the causal claim. "The convergence of findings across such disparate methods lends considerable strength to the main hypothesis that exposure to violent video games can increase aggressive behavior."109 They believe violent video games to be of more concern than violent television or films because of the identification with the game aggressor that players experience and the active participation in the virtual violence of the game. "In a sense, violent video games provide a complete learning environment for aggression, with simultaneous exposure to modeling, reinforcement, and rehearsal of behaviors. This combination of learning strategies has been shown to be more powerful than any of these methods used singly." 10

One of the authors of the study just discussed has, with a different coauthor, more recently published a meta-analysis of the current, developing research on the effects of violent video games. ${ }^{11}$ They identified thirty-five research reports, most of them experimental, laboratory studies, but including some field studies. Longitudinal studies were lacking, but that is unsurprising given the recent genesis of specific interest in violent video games. The metaanalysis led the authors to conclude that "[v]iolent video games increased aggression in males and females, in children and adults, and in experimental and nonexperimental settings." 12 The experimental studies showed that

108. Id.

109. Id. at 787 .

110. Id. at 788 (citations omitted).

111. See Craig A. Anderson \& Brad J. Bushman, Effects of Violent Video Games on Aggressive Behavior, Aggressive Cognition, Aggressive Affect, Psysiological Arousal, and Prosocial Behavior: A Meta-Analytic Review of the Scientific Literature, 12 PSYCHOL. SCI. 353 (2001).

112. Id. at 357 . 
"short-term exposure to violent video games causes at least a temporary increase in aggression," 113 while the nonexperimental studies demonstrate that "exposure to violent video games is correlated with aggression in the real world." 14 The study also showed that violent video games cause a decrease in prosocial behavior and are correlated to an unwillingness to help others in the real world, cause aggressive thoughts, and increase aggressive feelings. ${ }^{115}$

There is a study that has caused one court to call the science on the effect of violent video games "somewhat equivocal."116 The study cited, by Australian researchers Michele Fleming and Debra Rickwood, ${ }^{117}$ does not, however, really serve as a counterpoint to the studies already discussed. It is true that the study found no correlation between aggression and having played a violent video game, but the game employed in the study was of a far different nature than those in the other studies. The Australian study involved a population of eight to twelve year olds. The games compared the nonviolent game titled Bouncer II, which required moving about geometric figures, with what was considered a violent game. The violent game, Hero's Adventure, placed the player in the role of Hero, who travels through ancient Greece to rescue Persephone from Hades, and required the slaying of Cyclops monsters and skeletons. The study's authors suggest the possibility that the failure to find an aggressiveness inducing effect may result from the game not being seen as very violent. As they explain, "[f]or ethical reasons, a very 'mild' game was chosen." 18 In fact, the game was rated "G8+" indicating that no parental guidance was suggested for children eight and older. ${ }^{119}$ It is then perhaps not surprising that playing the game over a short period had no negative effect on children whose average age was ten years, six months. ${ }^{120}$ The authors suggest that the same result might not have been obtained had a more violent game been used. ${ }^{121}$

113. Id. (emphasis added).

114. Id. (footnote omitted).

115. See id. at 358.

116. Wilson v. Midway Games, Inc., 198 F. Supp. 2d 167, 182 n.33 (D. Conn. 2002). The comment comes in response to a claim that violent video games are addictive, but the two studies cited for the equivocal result regard the causation of aggressive behavior.

117. See Michele J. Fleming \& Debra J. Rickwood, Effects of Violent Versus Nonviolent Video Games on Children's Arousal, Aggressive Mood, and Positive Mood, 31 J. APPLIED SoC. PSYCHOL. 2047 (2001).

118. Id. at 2064.

119. See id. at 2052.

120. See id. at 2053.

121. See id. at 2065 . 
C. The Training and Instructional Danger of Video Games

In a more anecdotal vein, as opposed to a controlled study, is the nonetheless important work of Lieutenant Colonel Dave Grossman, who formerly taught psychology at the United States Military Academy. He offers a chilling comparison of the video games played by children and the training and conditioning in the military. ${ }^{122}$ Grossman examined studies of the actions of soldiers in combat and found a strong unwillingness to kill other human beings, an unwillingness that resulted in a firing rate in the neighborhood of only twenty percent in World War II; ${ }^{123}$ that is, only a small minority of American riflemen were willing to fire their weapons at the enemy. That firing rate was similar to the firing rates for American troops in earlier wars. In response to the World War II experience, the military undertook steps to change training in order to increase the firing rate. The changes had their desired effect. By the Korean War, the firing rate increased to fifty-five percent, and with more refinement in training the rate increased to between ninety to ninety-five percent for the Vietnam War. ${ }^{124}$

Grossman and DeGaetano, the coauthor of one of Grossman's books, find three things necessary to shooting and killing: the potential killer must have a gun, the skill to hit the target, and the willingness to take another's life. ${ }^{125}$ Armies have long supplied the first, and the recently developed training techniques provide the second and third. Earlier training by firing at bull's eye targets provided skill, at least as to the mechanics of accurately firing a weapon, but there may have been a lack of carry over to the real world. More recent use of pop-up figures of people provides a more realistic setting, requiring quick reaction and finding target zones on the human form. It is also a lesser jump from shooting at a human shaped target to a real person than it is from a bull's eye to a real person. Still better training came with the advent of computer simulations. Military trainees using computers "learn how to shoot, where to shoot, how to maneuver through possibly deadly combat situations, how to tell enemy from friend, and, most important, how to kill. The entire event of killing in combat can be simulated by a computer."126

122. See Dave Grossman, On Killng: The Psychological Cost of Learning to KILl IN WAR AND SOCIETY (1995); GROSSMAN \& DEGAETANO, supra note 14.

123. See GrosSMAN, supra note 122, at 250 ("In World War II, 75 to 80 percent of riflemen did not fire their weapons at an exposed enemy, even to save their lives and the lives of their friends."); GROSSMAN \& DEGAETANO, supra note 14, at 72 ("[T] he firing rate was a mere 15 percent among riflemen.").

124. See GrosSMAN, supra note 122, at 251.

125. See GrossmaN \& DEGAETANO, supra note 14, at 72-73.

126. Id. at 72 . 
The relevance of the changes in military training is the similarity to the video games currently played by children. ${ }^{127}$ For Grossman, the Paducah school killings show that video games provide children training in killing similar to that used in the military, but of course, without the discipline also learned in military training. It was Grossman and DeGaetano's description of Michael Carneal's actions that show the skill and suppression of natural impulses that went into the shootings and made them so deadly effective, and note that Carneal's training was limited to video game simulations. ${ }^{128}$

Video games not only appear to supply the skill necessary to be an efficient killer, they may also serve a role in overcoming the reluctance to kill. The military use of simulators not only generates skill in aiming a weapon; it helps develop a conditioned response in which the soldier fires, when faced by a particular set of circumstances. The response is reinforced by rewards for high scores, the dropping of the target, the award of marksmanship badges, and additional rewards ranging from praise to passes. ${ }^{129}$ It is reasonable to believe that dropping targets and attaining high scores provide similar reinforcement for efficient performance by children on equivalent video games.

Violent video games act against a background of other media violence providing the skills that may make deadly the aggressiveness that comes more generally from violent media. It would also seem that any desensitization regarding violence from the more passive media would be strengthened by the more active participation in the video game variety of media violence. Violent video games provide at least whatever causal effect on real world violence the other media provide and probably more through the active involvement in video game play. They have the further deadly effect of providing the skills to act on those aggressive impulses.

\section{Meeting Strict Scrutiny}

A properly drawn, narrowly framed statute ${ }^{130}$ restricting access by children to violent video games should meet strict scrutiny. It is difficult to conceive of a governmental purpose more compelling than the protection of

127. Grossman and DeGaetano say that the United States Army's simulator, Multipurpose Arcade Combat Simulator, is a modification of the Super Nintendo game Duck Hunt and that the Fire Arms Training Simulator used by many law enforcement agencies is "more or less identical" to the video game Time Crisis. Id. at 74.

128. See supra note 15-20 and accompanying text.

129. See GROSSMAN, supra note 122, at 254.

130. The drawing of such a statute is addressed infra notes 293-95 and accompanying text. 
the physical and psychological well being of the nation's youth. While courts have not seen the necessity of restricting access to violent passive media to further that interest, video games pose their own set of dangers that require restrictions on access by children. While Judge Posner may believe that video games have never caused anyone to commit a violent act or raised the level of violence anywhere, ${ }^{131}$ the United States Army would seem to disagree. Quite similar games, or simulators, have increased the willingness to commit what are violent, even if justified, acts by soldiers. It is implausible that providing the same training to children, especially without also providing the discipline taught in the armed forces, would not increase the likelihood of violence among the young.

Judge Posner also failed to appreciate the differences in interactivity between video games and the passive media. While all literature, television, and film may strive to involve the audience, that is not the same as the audience members participating in the action and outcome of the presentation. The army did not reach the firing rates it did by showing its trainees Guadalcanal Diary or The Sands of Iwo Jima; it was the interactivity of combat simulators that had the desired effect. The terrorist hijackers of the September 11 th attacks did not simply watch films or read books about flying, they spent time on simulators. Simulators provide instruction through feedback that the passive media cannot, no matter how hard they strive to involve the reader or viewer. In the military marksmanship or video game context, they also provide reward for performance, from medals to points, that strengthen response. Again, "violent video games provide a complete learning environment for aggression, with simultaneous exposure to modeling, reinforcement, and rehearsal of behaviors. This combination of learning strategies has been shown to be more powerful than any of these methods used singly." 132

\section{VIOLENCE AS OBSCENITY}

Consider a video arcade crammed full of machines with names like "Harem" and "Concubine." Twelve and thirteen year old boys, by making "the right moves" cause the images of attractive females to disrobe.

131. See Am. Amusement Mach. II, 244 F.3d at 578-79.

132. Anderson \& Dill, supra note 100, at 788 (citing Edward J. Barton, Developing Sharing: An Analysis of Modeling and Other Behavioral Techniques, 5 BEHAV. MODIFICATION 386 (1981); John H. Chambers \& Frank R. Ascione, The Effects of Prosocial and Aggressive Videogames on Children's Donating and Helping, 148 J. GENETIC PSYCHOL. 499 (1987); Geoffrey R. Loftus \& Elizabeth F. Loftus, Mind at Play: The Psychology of Video GAMES (1983)). 
Depending on the players' skill level, the boys then engage in any number of virtual reality ultimate sexual acts with those electronic beauties. Society would certainly find such game room activities by children unacceptable, and the courts would not stand in the way of regulation. ${ }^{133}$ Yet, every day teenagers engage in virtual ultimate violence, while the ability of society to prevent that sort of activity is questioned. The difference is that depictions of sexual content can be sufficiently explicit and offensive as to come within the obscenity exception to the protections offered by the First Amendment. ${ }^{134}$ The Seventh Circuit opinion in Am. Amusement Mach. II refused to consider the possibility that depictions could be obscene due solely to violent content, and that court is not alone in its refusal. ${ }^{135}$ The lower court in Am. Amusement Mach. I took a more expansive view of the obscenity exception, concluding that

[i]t would be an odd conception of the First Amendment ... that would allow a state to prevent a boy from purchasing a magazine containing pictures of topless women in provocative poses ... but give that same boy a constitutional right to train to become a sniper at the local arcade without his parent's permission. ${ }^{136}$

It would be an odd conception but one that is commonly held. The modern application of the obscenity exception has focussed solely on sexual and excretory activities, but that focus is the product of Victorian Era concerns and is a relatively recent narrowing of a focus that was far greater in constitutionally relevant eras. Properly understood, the obscenity exception would be seen to extend to sufficiently explicit and offensive depictions of violence. The arguments are more fully presented elsewhere but I conclude that the ordinary language meaning of "obscene," the case law in

133. Indeed, the video game industry has not even challenged such restriction. The Indianapolis ordinance, for example, provided restrictions not only on violent video game access but also on games with strong sexual content. The industry, however, was said by the lower court in American Amusement Machine Ass'n v. Kendrick to "have no quarrel with the Ordinance's restriction on children's access to games with 'strong sexual content." Am. Amusement Mach. Ass'n v. Kendrick, 115 F. Supp. 2d 943, 945 (S.D. Ind. 2000) [hereinafter Am. Amusement Mach. I], rev'd, 244 F.3d 572 (7th Cir.), cert. denied, 534 U.S. 994 (2001).

134. The obscenity exception was recognized in Roth v. United States, 354 U.S. 476 (1957).

135. See, e.g., Eclipse Enters., Inc. v. Gulotta, 134 F.3d 63 (2d Cir. 1997). The Supreme Court has never, however, directly ruled on the issue. In Winters v. New York, the Court did declare unconstitutional a statute preventing the sale of material "principally made up of criminal news, police reports, or accounts of criminal deeds, or pictures, or stories of deeds of bloodshed, lust or crime," but it did so on vagueness grounds and wamed against concluding that the state lacked all authority to regulate violent material. Winters v. New York, 333 U.S. 507, 508 (1948).

136. Am. Amusement Mach. I, 115 F. Supp. 2d at 981. 
constitutionally relevant periods, and the first amendment policy arguments that justifiy the obscenity exception all speak just as well to violence as to sex..$^{137}$

\section{A. The Ordinary Language Concept}

As a term of ordinary language, "obscene" has a broader extension than both sex and violence, as in talk of a company making obscene profits. But even more rigorous examinations of the word, based on its derivation, would include violence with sex. The derivation of the word "obscene" has been argued to be either from "ob caenum," or "on account of filth" or simply "filth," 138 or from "ab scaena" or "off the stage," which could mean either "not to be openly shown on the stage of life"139 or instead "off the theatrical stage." 140 Professor Harry Clor offers an analysis of the word "obscene" that speaks to both the idea of filth and the "off the stage of life" derivation. He suggests that obscene depictions are those that offer "a degradation of the human dimensions of life to a sub-human or merely physical level."141 Further, obscene literature is, for Clor, that which "presents, graphically and in detail, a degrading picture of human life and invites the reader or viewer, not to contemplate that picture, but to wallow in it." 142 Clor goes on to include the "off the stage of life" derivation, writing "obscenity consists in making public that which is private; it consists in an intrusion upon intimate physical processes and acts or physical-emotional states." ${ }^{43}$ The two are tied together in that "when the intimacies of life are exposed to public view their human value may be depreciated." 144

137. See SAUNDERS, supra note 57; Kevin W. Saunders, Media Violence and the Obscenity Exception to the First Amendment, 3 WM. \& MARY BILL RTS. J. 107 (1994); Kevin W. Saunders, Media Self-Regulation of Depictions of Violence: A Last Opportunity, 47 OKLA. L. REV. 445 (1994).

138. See, e.g., HARRY M. ClOR, OBSCENITy AND PUBlic MoRAlITY: CENSORSHIP IN A LiBerAl SOCIETY 210 (1969); Andrea Dworkin, Against the Male Flood: Censorship, Pornography, and Equality, 8 HARV. WOMEN's L.J. 1, 7 (1985).

139. CLOR, supra note 138, at 210 (footnote omitted).

140. See, e.g., RICHARD H. KUH, FOOLISH FIGLEAVES? PORNOGRAPHY IN-AND OUT OFCOURT 335-36 n.l (1967) (quoting Walter Allen, The Writer and the Frontiers of Tolerance, in "TO DEPRAVE AND CORRUPT . . ": ORIGINAL STUDIES IN THE NATURE AND DEFINITION OF "OBSCENITY" 147 (John Chandos ed., 1962)) ("Obscenity seems originally to have meant that which could not be represented upon the stage. It is related to ancient Greek theories of drama.").

141. ClOR, supra note 138 , at 225 .

142. Id. at 234.

143. Id. at 225 .

144. Id. 
Under this insightful approach, it is not the focus on sex that can make a depiction obscene; it is the treatment of human beings in a purely physical way with regard to acts or activities that also have great emotional or spiritual importance. "The element of obscenity ... consists in one's being 'too close' to other persons performing intimate physical acts." 145 We withhold from view acts and events that have both spiritual and physical sides but for which an observer can experience only the physical, subhuman aspects of the act. ${ }^{146}$ This approach explains the private nature of sex and excretory activities, but it also would include other physical drives or inevitiablities, anything that focuses solely on the physical side of human existence. ${ }^{147}$ A romantic film has a focus on the human spirit that should, under Clor's approach, be nonobscene, even with explicit sex, as long as the physical acts are in a context that provides human, as opposed to solely animal, meaning. The same would, under this analysis, carry over to violence. A death scene that considers human values concerning life and death and relationships to those close to the departed does not have a sole focus on the physical that is present in the slasher film, and sufficient violence for its own sake should be considered as obscene as explicit sexual depictions for their own sake. In fact, Clor reaches this conclusion himself, writing that an obscene depiction is "one which tends predominantly to ... [v]isually portray in detail, or graphically describe in lurid detail, the violent physical destruction, torture, or dismemberment of a human being, provided this is done to exploit morbid or shameful interest in these matters and not for genuine scientific, educational, or artistic purposes." $148 \mathrm{He}$ also includes as obscene similarly lurid depictions or descriptions of death or of dead bodies. ${ }^{149}$

The "off the [theatrical] stage" derivation of "obscene" has the advantage of tying the concept to its area of application; that is, since the ascription is used to indicate that which can be banned from the entertainment

145. Id.

146. See id. at 226.

There are certain bodily acts which will tend to arouse disgust in an observer who is not involved in the act and is not, at the time, subject to its urgencies. What the observer sees is a human being governed by physiological urges and functions. Now, to the participants, the act . . . can have important personal and supra-biological meanings. But the outside observer cannot share the experience of these meanings; what he sees is simply the biological process.

ClOR, supra note 138 , at 226.

147. See id. at 225. ("[T] here can ... be obscene views of death, of birth, of illness, and of acts such as that of eating .... Obscenity makes a public exhibition of these phenomena and does so in such a way that their larger human context is lost or depreciated.").

148. Id. at 245.

149. See id. 
media, what has historically been banned in that arena should cast light on what is included within the concept. The history of what has been considered obscene in that regard clearly shows that in different eras violence has been banned from the stage. In those eras it was ab scaena, or off stage, and in some of those eras sex was not as restricted. Greek drama was quite tolerant of sexual themes in comedies but intolerant of violence. The sexual content does not match that of modern "adult films," but it does not require a journey too far into our society's past to find an era in which Aristophanes would have been shocking. Aristophanes' The Clouds and Lysistrata both have sexual content, ${ }^{150}$ again not to the point of modern film, but Lysistrata was subject to customs seizure during the first thirty years of this century and, as late as 1955 , was considered obscene by the Post Office. ${ }^{151}$

The Greek treatment of violence was more restrictive. Descriptions of violence and even some audience exposure were allowed. In Sophocles' Electra, Clytemnestra is killed by her son in a house out of the view of the audience, but her voice is heard. ${ }^{152}$ In Euripides' Hecuba, Polymestor's sons are killed and Polymestor is blinded in a tent set up on stage, to the accompaniment of screams and battering on the walls of the tent. ${ }^{153}$ What Greek drama did not allow was the visual depiction of violent death. "When the plot of [a] play ... required such an incident, the harrowing details were narrated by a messenger who had witnessed the event."154 "We are led up to the point where some violent deed is going to take place, given the motives for the deed and the story behind it, but the deed itself takes place off stage."155

Roman theater, at least later Roman theater, certainly allowed a great deal of violence. A society in which mortal combat is a form of entertainment does not share the Greek aversion to violence on the stage. It is claimed that in the performance of a play, a slave was forced to play the role of a person killed by wild beasts and was actually killed by a bear on stage. ${ }^{156}$ While violence was explicit and real, so were sexual performances in that same late

150. See Four Plays By ARISTOPhaNes (William Arrowsmith et al. trans., First Meridian Classic Printing 1984).

151. See H. MONTGOMERY HYDE, A HISTORY OF PORNOGRAPHY 40 (1964) (citing JAMES C. N. Paul \& MURRay L. SCHWARTZ, Federal CENSORShIP: OBSCENITY IN the MAIL 104 (1961)).

152. See The COMPLETE Plays OF SOPHOCles (Sir Richard Claverhouse Jebb trans., Moses Hadas ed., 1967).

153. See EURIPIDES III (David Grene \& Richmond Lattimore eds., 1958).

154. ROY C. FLICKINGER, THE GREEK THEATER AND ITS DRAMA 127-28 (4th ed. 1936).

155. PETER D. ARNOTt, AN INTROduCtion to THE GReEK THEATRE 22 (1959).

156. See RiCHARd C. BEACHAM, THE ROMAN THEATRE AND ITS AUdiENCE 136 (1991) (The play was Catullus' Laureolus.). 
Roman theater. ${ }^{157}$ It was not the case that the focus of obscenity had shifted from violence to sex; it had simply lost focus.

Medieval drama also appears not to have been so averse to violence. In religious plays portraying the lives of the martyrs violence seemed common. ${ }^{158}$ It is also the case that the classics of English drama contained violence. Many of Shakespeare's plays were set against a background of violence. Despite the existence of violence, it is important to note that Shakespeare's plays were not as violent as they could have been and that some violence occurs off the stage. In Titus Andronicus, a play considered Shakespeare's grisliest, ${ }^{159}$ the worst of the violence is behind the scenes. Lavinia is raped, and her hands are cut off and her tongue cut out. The violence against her is described and she appears on stage with bleeding mouth and bloody stumps where her hands were, but Shakespeare chose not to show the violence.

While there may have been a tolerance for violence in the era, in some regions there also seems to have been a tolerance for sexual displays. Human intercourse served to entertain select audiences in France from the Renaissance through part of the 18th century, and copulating animals were a common exhibition in the same era in a number of European societies. ${ }^{160}$ What should be clear is that "obscene" as "off the theatrical stage" has not, historically, had sole application to sexual or excretory activities. The treatments of violence and sex differ from era to era, and neither can claim the sole right to the ascription "obscene." Thus, under any of the derivations and ordinary language analyses of the word or concept, obscenity encompasses violence as well as it does sex.

\section{B. Legal History}

When the Supreme Court recognized the obscenity exception in Roth $v$. United States, ${ }^{161}$ it did so, at least in part, on the basis of a legal history that indicated obscene material was never seen as protected by the First Amendment. The Court recognized restrictions on speech in the colonial era and indications that, at the time of the First Amendment, obscenity was among

157. See id. at 137.

158. See John Spalding Gatton, 'There Must Be Blood': Mutilation and Martyrdom on the Medieval Stage, in VIOLENCE IN Drama 79 (James Redmond ed., 1991).

159. For a description of the play and an analysis of the violence see Jonas Barish, Shakespearean Violence: A Preliminary Survey, in VIOLENCE IN DRAMA 101 (James Redmond ed., 1991).

160. See Eberhard Kronhausen \& Phyllis Kronhausen, Pornography and the LAW: THE PSYCHOLOGY OF EROTIC REALISM AND PORNOGRAPHY 66-67 (1964).

161. 354 U.S. 476 (1957). 
the forms that were restricted. ${ }^{162}$ What the Court failed to note is that the statutes cited, while they did prohibit obscenity, failed to define what was obscene.

Professor Schauer notes a lack of definition for obscenity in English law until 1868. ${ }^{163}$ In American law a focus on sex appeared to be developing in the mid to late 1800 s, but Schauer finds it finally clear only with the 1896 decision in Swearingen $v$. United States ${ }^{164}$ that obscenity focused solely on sexually oriented material. That focus on sex then developed only in a constitutionally irrelevant era as a part of the Victorian Era preoccupation with sexual regulation. Such an 1896 definition should not be mistaken for a definition in the era of the Bill of Rights, and if laws banning the obscene in that era or shortly thereafter serve to justify the existence of the exception, it is not a later legal definition that sets the scope of that unprotected material but an earlier, broader concept that goes beyond sex.

The inclusion of violence within that concept is indicated by the states' reactions to the developing focus of obscenity on sex. When the use of the word "obscene" became limited to sexual material, the states stepped in to pass statutes regulating violence. What might have been restricted as obscene before now needed its own statute. Indeed, the New York group established by the anti-obscenity crusader Anthony Comstock also led the effort to establish a New York statute prohibiting the distribution of "any book, pamphlet, magazine, newspaper or other printed paper devoted to the publication, and principally made up of criminal news, police reports, or accounts of criminal deeds, or pictures, or stories of deeds of bloodshed, lust or crime." 165 Although the statute was held to be unconstitutionally vague in Winters $v$. New York, ${ }^{166}$ it does reflect a concern shared by a majority of the states in existence in the late 1800 s and early 1900 s, as shown by nineteen nearly identical and four substantially similar statutes. ${ }^{167}$ Some of those statutes continued to use the word "obscene" in their titles; ${ }^{168}$ they may be viewed as insisting that the category of the obscene is not so limited. Other states, by enacting statutes addressed to material no longer covered by obscenity statutes and not insisting on maintaining the label, may be seen as wishing to continue to ban such material without being concerned over the label to be applied.

162. See Roth v. United States, 354 U.S. 476, 483 (1957).

163. See FREDERICK F. SCHAUER, THE LAW OF OBSCENITY 7 (1976).

164. 161 U.S. 446 (1896).

165. Winters, 333 U.S. at 508 (citations omitted).

166. 333 U.S. 507 (1948).

167. See Winters, 333 U.S. at 522-23 (Frankfurter, J., dissenting).

168. The statutes are discussed in SAUNDERS, supra note 57, at 114-19. 
The history that was said to justify the obscenity exception then justifies an exception that encompasses violence rather than one limited to sex. The law in the Constitutional era and the era of the Bill of Rights denied protection to obscenity, but obscenity had not acquired a narrow focus on sex. The era in which that focus developed is a constitutionally irrelevant time, and the fact that the states continued to suppress violent material, some even continuing to call it obscene, provides as long a history of addressing concerns of violent depiction as that for addressing sex.

\section{Policy Bases}

In addition to the historical bases for banning the obscene, the Roth Court and various commentators have presented policy reasons for denying first amendment protection to obscene materials. The policy analysis has been limited to the consideration of depictions of sexual activity, but the policy reasons carry over with equal weight to obscene violence. Only two such justifications are examined here, at opposite extremes of first amendment protectiveness, while still justifying the obscenity exception, but an examination of other justifications yields similar results. ${ }^{169}$

Roth took the position that the First Amendment was intended to assure the free interchange of ideas to bring about "political and social changes desired by the people." 170 This rationale is similar to what Professor Blasi called the First Amendment's "checking value," the role that "free speech, a free press, and free assembly can serve in checking the abuse of power by public officials." ${ }^{771}$ It also reflects Professor Meiklejohn's theory that for speech to enjoy first amendment protection it should relate to selfgovernance. ${ }^{172}$

The "checking value" or self-governance view of the scope of first amendment protection would deny such protection to sexual obscenity. While pornography may be used as a medium for political expression, pornography is only obscene, under the rule in Miller $v$. California, ${ }^{173}$ if it "lacks serious literary, artistic, political, or scientific value." 174 If obscene, it is not seriously political pornography. The important point here is that, just as sexual

169. See id. at $135-60$.

170. Roth, 354 U.S. at 484.

171. Vincent Blasi, The Checking Value in First Amendment Theory, 1977 AM. B. FOUND. RES. J. 521, 527 (1977).

172. See Alexander Meiklejohn, Free SPEech and Its Relation to SelfGOVERNMENT (1948).

173. 413 U.S. 15 (1973).

174. Miller v. California, 413 U.S. 15, 24 (1973). 
obscenity lacks protection under the "checking value" or self-governance theories, so also does violent obscenity, if properly defined. If the Miller definition of obscenity is adapted to allow a ban on explicit depictions of violence only when such depictions lack "serious literary, artistic, political, or scientific value," then any work considered violent obscenity would by definition not have serious political value. ${ }^{175}$ So, just as sexually obscene works without serious political value are unprotected under the "checking value" model of the First Amendment, violently obscene works should be unprotected.

If the values found so central by Blasi and Meiklejohn provided the limits of first amendment protections, that would be the end of the argument. However, while the values they and the Roth opinion identify are certainly important and may be viewed as core values, the Amendment does protect other expression. Literature, art, and entertainment are also protected, so other justifications for the exception must be considered.

Professor Schauer justifies the exception, despite a broad view of first amendment protection, by arguing that sexual obscenity departs completely from the sphere of protected speech and is in fact nonspeech. He discusses what he admits is a hypothetical extreme example of hard core pornography. The hypothetical ten-minute film is nothing but a close up of sexual organs engaged in intercourse, with no dialogue, no music, and no attempt at artistic depiction. Schauer argues that:

[A]ny definition of 'speech' $\ldots$ that included this film ... is being bizarrely literal or formalistic. Here the vendor is selling a product for the purpose of inducing immediate sexual stimulation. There are virtually no differences in intent and effect from the sale of a plastic or vibrating sex aid, the sale of a body through prostitution, or the sex act itself. At its most extreme, hard core pornography is a sex aid, no more and no less, and the fact that there is no physical contact is only fortuitous. ${ }^{176}$

If pornography is simply a sex aid, it deserves, in Schauer's view, no protection and should be treated similarly to any physical device designed to stimulate. The fact that the stimulating experience is initiated visually, rather than by tactile means, is irrelevant. It does not really involve communication.

There is, of course, a mental element to pornography-caused sexual arousal. The visual images must be processed by the brain before any effect can result. While a physical stimulator does not require any higher level mental information processing for its effects, the mental element to pornography based arousal is not sufficiently distinguishing. The objection to including sexually obscene materials within even this broad view of the

175. Miller, 413 U.S. at 24.

176. Frederick Schauer, Free Speech: A Philosophical Enquiry 181 (1982) (footnote omitted). 
protections of freedom of speech appears to be that the brain is not its final audience or even a co-equal audience. While music, art, and romantic literature may stimulate, they also communicate other messages aimed at the intellect. The brain is at least a co-equal audience. The position that an intellectual experience is more protected than a visceral response seems reasonable. It also seems reasonable, however, to treat visceral responses involving the adrenal glands in the same way as visceral responses involving the genitals. If material is violent enough to have a hormonal effect, even Schauer's broad view would not reach such material and should not provide first amendment protection.

There are, of course, first amendment theories that speak against the existence of a sexual obscenity exception and would also speak against an exception for violent obscenity. ${ }^{177}$ Nonetheless, the obscenity exception is a part of the law. As long as it is a part of the law, the interesting theories are those that justify it. There appear to be no such theories that would not also justify an exception for violent obscenity. Given the history, both in drama and law, the ordinary language uses of the term, and the inability to distinguish the two under first amendment theory, the law should allow a refocusing of the obscenity exception to include violence.

\section{Children and Variable Obscenity}

The district court opinion in Am. Amusement Mach. I recognized the effect that depictions of violence can potentially be obscene has on limiting youth access to violent video games. The first sentence of the opinion reads: "The First Amendment does not prohibit states from restricting children's access to pornography even though adults' access to the same sexually explicit materials may not be restricted." 178 The materials at issue in Am. Amusement Mach. I were not sexually explicit and thus not pornographic, but the court saw a parallel in the treatment of pornography that carried over to the games that were of concern to Indianapolis. The court relied strongly on the Supreme Court's decision in Ginsberg $v$. New York, ${ }^{179}$ which recognized the distinction present in the language quoted. Ginsberg invoked the doctrine of variable obscenity to uphold a conviction for selling what it characterized as "girlie magazines" to a minor. While the magazines would not be obscene

177. The work of Professor Edwin Baker, based on free speech as a part of autonomy, provides an example. See, e.g., C. EDWIN BAKER, HUMAN LIBERTY AND FREEDOM OF SPEECH (1989).

178. Am. Amusement Mach. I, 115 F. Supp. 2 d at 945 (citing Ginsberg v. New York, 390 U.S. 629 (1968)).

179. 390 U.S. 629 (1968). 
when sold to adults, the Court said that the audience can be taken into account. The prurient interests of the teenage male being more easily piqued, provocatively posed nudes may be obscene for that audience, even if insufficiently offensive and explicit to be obscene for adults. New York's restriction on distributing material to minors that is "harmful to minors," which the statute defined as material that "(i) predominantly appeals to the prurient, shameful or morbid interest of minors, and (ii) is patently offensive to prevailing standards in the adult community as a whole with respect to what is suitable material for minors, and (iii) is utterly without redeeming social importance for minors, $"{ }^{180}$ was held constitutional.

Earlier courts had been faced with the argument that Ginsberg allowed the state to limit the access of children to violent materials but had rejected the claim. The Eight Circuit, in Video Software Dealers Ass' $n$ v. Webster, ${ }^{181}$ struck down a Missouri statute that banned the rental or sale to minors of violent videos. The court rejected the state's reliance on Ginsberg, because Ginsberg applied not to violence but only to material that is obscene as to minors. The Supreme Court of Tennessee reached the same conclusion regarding a similar statute in that state. ${ }^{182}$ Reaching a different ultimate conclusion regarding the applicability of Ginsberg to a violent video game statute and finding it constitutional on that basis requires the recognition that depictions of violence are potentially obscene. Only then can the doctrine of variable obscenity be employed to conclude that violent material that would be acceptable for adults may be restricted when the consumer is a minor.

\section{E. Obscenity and Offence}

Judge Posner, in the Seventh Circuit Am. Amusement Mach. II opinion, addressed and rejected the application of Ginsberg, concluding that "[v]iolence and obscenity are distinct categories of objectionable depiction." 183 The difference between the two, as Judge Posner saw it, is that the violent video game statute at issue was motivated by concerns over the violence inducing effects the government saw in such activities, while "[t]he main worry about obscenity, the main reason for its proscription, is ... that

180. Ginsberg v. New York, 390 U.S. 629, 633 (1968) (citations omitted).

181. 968 F.2d 684 (8th Cir. 1992).

182. See Davis-Kidd Booksellers, Inc. v. McWherter, 866 S.W.2d 520 (Tenn. 1993).

183. Am. Amusement Mach. Ass'n v. Kendrick, 244 F.3d 572, 574 (7th Cir.) [hereinafter Am. Amusement Mach. II], cert. denied, 534 U.S. 994 (2001) (citing Winters, 333 U.S. at 518-20; United States v. Thoma, 726 F.2d 1191, 1200 (7th Cir. 1984)). 
it is offensive." 184 He did allow that it is imaginable that an ordinance could be directed at depictions of violence because of offensiveness but said that was not the basis of Indianapolis' ordinance and that the games introduced into evidence were themselves not offensive. ${ }^{185}$

It is unclear why the government must be motivated by offensiveness. If a city had not had an ordinance like that in Ginsberg limiting the access of minors to sexually provocative materials not obscene for adult audiences, but came to believe that such materials were contributing to teenage pregnancies, it would seem that Ginsberg would support a properly drawn ordinance even so motivated. Indeed, if a state did not have an obscenity statute and chose to adopt one out of a concern that the presence of such materials has a negative effect on marriage, Roth would still seem to support such a law, as long as it met the test of Miller. If material is obscene, or obscene as to minors and distributed to that audience, it is unprotected by the First Amendment, and whatever rational motive the state may have will justify the limitation.

It is true that under Miller, to be found obscene a work must be patently offensive, and any extension to violence would require a similar finding of offensiveness, ${ }^{186}$ but the Indianapolis ordinance did so require. The ordinance limited minor access only to those games that are "patently offensive to prevailing standards in the adult community as a whole with respect to what is suitable material for persons under the age of eighteen." 187 This is a precise parallel to the language in the New York statute upheld by the Supreme Court in Ginsberg with only "persons under eighteen" substituted for the New York statutes use of "minors."188

184. Am. Amusement Mach. II, 244 F.3d at 574. The United States Court of Appeals for the Sixth Circuit also recently made this same point, citing the Seventh Circuit's $A m$. Amusement Mach. II opinion. See James v. Meow Media, Inc., 300 F.3d 683, 698 (6th Cir. 2002), cert. denied, U.S. , 123 S. Ct. 967 (2003). The Sixth Circuit's consideration arose in the context of a tort case brought by the parents of victims of the Paducah shootings against media defendants said to have influenced Michael Carneal, the shooter. See James, 300 F.3d at 686. The tort setting adds to the difficulties of applying obscenity theory. See id. at 696. The major additional issue is the lack of a statute clearly setting out the sort of depictions that may be considered obscene and the chilling effect that would have on the media. The Sixth Circuit pointed to that issue, but it is also clear that the court declined to extend the invitation to extend obscenity law in this direction. See id. at 697.

185. See Am. Amusement Mach. II, 244 F.3d at 575.

186. See Miller, 413 U.S. at 24.

187. Am. Amusement Mach. I, 115 F. Supp. 2d at 946 (citations omitted).

188. See Ginsberg, 390 U.S. at 633. The statute in Ginsberg was addressed to distribution to those under seventeen, rather than eighteen as in the Indianapolis ordinance. See id. That raises a separate issue to be discussed infra notes 283-86 and accompanying text, but does not affect the issue of offensiveness. 
Judge Posner does seem to allow that some depictions of violence could be considered offensive, perhaps even to the point of being obscene. ${ }^{189}$

One can imagine an ordinance directed at depictions of violence because they, too, were offensive. Maybe violent photographs of a person being drawn and quartered could be suppressed as disgusting, embarrassing, degrading, or disturbing without proof that they were likely to cause any of the viewers to commit a violent act. They might even be described as "obscene," in the same way that photographs of people defecating might be, and in many obscenity statutes are, included within the legal category of the obscene. ${ }^{190}$

He goes on to state, however, that the only games in the record are not so sufficiently disgusting.

The most violent game in the record, "The House of the Dead," depicts zombies being killed flamboyantly, with much severing of limbs and effusion of blood; but so stylized and patently fictitious is the cartoon-like depiction that no one would suppose it "obscene" in the sense in which a photograph of a person being decapitated might be described as "obscene." 191

Despite the cartoon, and thus obviously fictitious nature of the action, it is not clear why the depictions cannot be obscene, if Judge Posner is truly willing to allow depictions of violence to fall within the category.

It must be remembered that the restrictions apply to children, and the measure of obscenity is different where that is the audience. If the game involved stylized and patently fictitious zombies engaged in sex as explicit as the violence he describes, it would most likely not be found obscene for an adult audience but might well be for an audience of children. A similar comparison could be drawn for defecating zombies. Furthermore, it is not whether an adult judge or any other adult finds the images offensive for personal viewing. It is, as the statute upheld for sexual material in Ginsberg said, whether the material "is patently offensive to prevailing standards in the adult community as a whole with respect to what is suitable material for minors." 192

Even though Judge Posner seemed to leave open the possibility that violence could be sufficiently offensive as to be obscene, his distinction between obscenity as offensive and violence as of concern only because of the harm that it is seen, by someone other than Judge Posner, to cause seems to indicate a belief in the unlikelihood of the public finding such offense. ${ }^{193}$ If that is what is behind the opinion, the conclusion may simply be wrong. A

189. See, e.g., Am. Amusement Mach. II, 244 F.3d at 575.

190. Id. (citations omitted).

191. Id.

192. Ginsberg, 390 U.S. at 633 (citations omitted).

193. See Am. Amusement Mach. II, 244 F.3d at 574-75. 
team of media researchers led by Professors Daniel Linz and Edward Donnerstein conducted a study that speaks rather directly to the issue. ${ }^{194}$ Their study involved exposing a population in the Memphis, Tennessee area to sexual and violent films and surveying their reactions. ${ }^{195}$ The sexual films were selected based on obscenity prosecutions indicating prosecutor beliefs that the films violated community standards for offensiveness. ${ }^{196}$ The violent films were of the "slasher" variety. ${ }^{197}$ The participants were asked to assess the films in terms of whether they found the films acceptable and also whether they thought their communities found them acceptable. ${ }^{198}$ Summarizing their results, the scientists concluded that the adults found the sexual films not to be patently offensive, while the violent films were seen as exceeding their standards for offensiveness. ${ }^{199}$ "The majority of our sample of community members ... appeared not to personally accept violent slasher films." ${ }^{200}$ What is particularly interesting is that

despite a lack of personal acceptance for violence among the majority of participants ..., a large majority both before and after viewing the [violent] material did indicate that others in the community tolerated these materials. This finding is interesting in light of our previous work on community members in Charlotte, NC, which showed that these citizens personally accepted sexually explicit depictions but judged others in the community to be intolerant of them. ${ }^{201}$

If those results accurately represent the population, then the participants must be wrong. Respondents do not tolerate violence but think that their community does, but they are the community (or are representative of it), so the real situation is that the community in a sense does not tolerate violence but thinks that it does. That is, the average person finds the material offensive but believes himself or herself to be out of step with public sentiment. To the contrary with sexual material; the average person does not take offense but believes that other members of the community are offended. Judge Posner,

194. See generally Daniel Linz et al., Discrepancies Between the Legal Code and Community Standards for Sex and Violence: An Empirical Challenge to Traditional Assumptions in Obscenity Law, 29 LAW \& SOC'Y REV. 127 (1995) [hereinafter Linz et al., Discrepancies Between the Legal Code and Community Standards].

195. See id. at 137.

196. See id. at 136.

197. See id. at 139.

198. See id. at 141.

199. See id. at 155-56.

200. Linz et al., Discrepancies Between the Legal Code and Community Standards, supra note 194 , at 157 .

201. Id. at 158-59 (footnote omitted) (citing Daniel Linz et al., Estimating Community Standards: The Use of Social Science Evidence in an Obscenity Prosecution, 55 PUB. OPINION Q. 80(1991)). 
whether he does or does not personally find violent depictions offensive, may have failed to recognize the degree to which the public does find such images offensive.

Judge Posner raises one additional argument against applying an obscenity approach to the exposure of children to depictions of violence. ${ }^{202}$ It speaks to what he sees as a historical acceptance of violence as fare for children and would, thus, also reinforce his argument that such depictions are not seen as offensive, even with regard to what is suitable for children. ${ }^{203} \mathrm{He}$ writes: "Violence has always been and remains a central interest of humankind and a recurrent, even obsessive theme of culture both high and low. It engages the interest of children from an early age, as anyone familiar with the classic fairy tales collected by Grimm, Andersen, and Perrault is aware."204 But of course, all but the last clause of the quote would read just as well and be just as true with "sex" substituted for "violence" without it serving to strike down limitations on the exposure of children to sexual images. With regard to that last clause, the comparison of Hansel and Gretel's encounter with a witch is as far from the modern slasher film as Prince Charming kissing Sleeping Beauty is from X-rated films. ${ }^{205}$

Fairy tales do contain a great deal of violence, but much of the violence is in a clear fantasy realm. Hansel and Gretel do trick a witch into an oven intended for them, but it is a witch and the action occurs in a place where houses are made of bread. ${ }^{206}$ Furthermore, even the Grimms Brothers' versions are toned down. Their Little Red Riding Hood is rescued from the stomach of the wolf, while in earlier versions she was not so fortunate. ${ }^{207}$ But, even there, it was a wolf capable of speech and impersonating a grandmother. While other instances of violence may not be set in quite so obvious a fantasy world,

[i]n the Grimms' collection, the true horror stories are not so much tales based on the victimization/retaliation model as cautionary tales-texts that rely on a transgression/punishment model for their plotting. These stories end with the triumph of adult wisdom over childish disobedience, curiosity, or naughtiness.

202. See Am. Amusement Mach. II, 244 F.3d at 577.

203. See id.

204. Id. at 577.

205. It appears that the earlier tale out of which Sleeping Beauty came was closer to Xrated. In an early Italian version, Prince Not-So-Charming is a married king who comes upon Sleeping Beauty, rapes her, and leaves her pregnant. See MARIA TATAR, THE HARD FACTS OF THE GRIMMS' FAIRY TALES 139 (1987) [hereinafter TATAR, THE HARD FACTS].

206. See MARIA TATAR, OfF WITH THEIR HeAdS! Fairy TALES AND THE CULTURE OF CHILDHOOD 208-09 (1992).

207. See id. at 7-8. Little Red Riding Hood was also toned down in sexuality. See id. at 3 . Earlier versions had her escape after performing a striptease for the wolf. See id. 
$\cdots$

[Tales with particularly strong punishment of children] seem consciously designed to impart specific lessons framed by adults for children. As cautionary tales, they demonstrate how children with undesirable traits-deceitfulness, curiosity, insolence-come to a bad end. ${ }^{208}$

They are then morality plays for children, not simply early slasher stories.

There is one additional point here. While the Grimms Brothers', and even more so Perrault's, versions of the fairy tales were rather violent, there is not as much violence in the film versions provided by film makers such as Disney. ${ }^{209}$ That is an important point. Given the impact of film on the sort of visceral response that seems the hallmark of obscenity, the existence of violence in the oral tradition of fairy tales, especially coupled with criticism of even that genre's suitability for children, ${ }^{210}$ may not provide the justification Judge Posner sees for the far more realistic and visually explicit violence of many films and video games.

\section{VIDEO GAMES AS UNPROTECTED BY THE FIRST AMENDMENT}

\section{A. Early Video Games}

When Judge Limbaugh concluded in the St. Louis case that video games do not enjoy the protections of the First Amendment, he was not striking out on completely new ground. ${ }^{211}$ The idea that video games would enjoy no first amendment protection may seem odd, but there is the foundation for such a position in case law. The line is not long, since video games are a relatively recent development. The first in the line is America's Best Family Showplace Corp. v. City of New York, ${ }^{212}$ a 1982 case in a New York federal district court. A restaurant operator in the Borough of Queens wanted to install coin operated video games in forty dining tables, and the Borough rejected the plan under an ordinance limiting video games in businesses such as restaurants, gift

208. TATAR, THE HARD FACTS, supra note 205, at 191-92.

209. See id. at $239 \mathrm{n} .28$ (noting that Disney lessened the emphasis on the evil queen by concentrating on the dwarves, who had not even been named in the Grimms' version). While there are certainly evil characters in film versions, the evil queen or step-mother remaining in those versions, the treatment of victims does not approach the barbarity of hacking people to pieces or children literally butchering each other. $I d$. at 3-5, 181 .

210. See, e.g., id. at 185 (noting that Grimms' fairy tales have come under "heavy fire" from educators).

211. See Interactive Digital Software Ass'n v. St. Louis County, 200 F. Supp. 2d 1126 , 1134-35, 1141 (E.D. Mo. 2002).

212. 536 F. Supp. 170 (E.D.N.Y. 1982). 
shops, and record stores to no more than four. ${ }^{213}$ The restauranteur brought suit claiming that the restriction was a violation of his first amendment rights. ${ }^{214}$

The court saw the dispositive question as whether or not video games are expression enjoying first amendment protection. ${ }^{215}$ The plaintiff argued that video games bring "visual and aural presentations on a screen involving a fantasy experience in which the player participates" and are sufficiently akin to a motion picture to enjoy the protection of the Amendment. ${ }^{216}$ Support was drawn from a Supreme Court case holding that a coin operated device permitting a customer to view live, nude dancing behind a glass panel was entertainment protected by the Constitution. ${ }^{217}$ The court, however, was unconvinced, responding that while the Supreme Court has protected nude dancing, "it seems clear that before entertainment is accorded First Amendment protection there must be some element of information or some idea being communicated. That element is clearly lacking here." ${ }^{18}$ Motion pictures, while entertainment, are protected because they may be used to convey ideas and affect public opinion, and trying to draw a line between entertaining and informing in such a medium is "too elusive for the protection of that basic right." ${ }^{219}$ Turning to the issue at hand, the court said: "In no sense can it be said that video games are meant to inform. Rather, a video game, like a pinball game, a game of chess, or a game of baseball, is pure entertainment with no informational element."220 Thus, no line between entertaining and informing had to be drawn, and video games could be denied the protection of the First Amendment and the limit of four games upheld. ${ }^{221}$

Several other courts followed the lead of the America's Best court. In the 1983 case Caswell v. Licensing Commission, ${ }^{222}$ the Massachusetts Supreme Court considered a similar free expression claim in the review of the

213. See America's Best Family Showplace Corp. v. City of New York, 536 F. Supp. 170, 171 (E.D.N.Y. 1982).

214. See America's Best, 536 F. Supp. at 171.

215. See id. at 173.

216. Id. (citations omitted).

217. See id. The plaintiff cited to Schad v. Borough of Mount Ephraim, 452 U.S. 61 (1981).

218. America's Best, $536 \mathrm{~F}$. Supp. at 173 (citations omitted).

219. Id. at 174 (quoting Winters v. New York, 333 U.S. 507, 510 (1948)).

220. Id. at 174. The court claimed support from Stern Electronics, Inc. v. Kaufman, but that case examined copyright issues involving video games rather than First Amendment protections. See Stern Elecs., Inc. v. Kaufman, 669 F.2d 852, 857 (2d Cir. 1982).

221. See America's Best, 536 F. Supp. at 174.

222. 444 N.E.2d 922 (Mass. 1983). 
denial of a license for video games in a proposed arcade. ${ }^{223}$ The court again said that such protection attaches only to the communication or expression of some idea or information. ${ }^{224}$ The court noted cases regarding roller skating and recreational dancing that found no first amendment protection in such activities because they were not meant to communicate to or entertain an audience; they were not performances but were instead physical exercises and activities engaged in for the attainment of personal pleasure. ${ }^{225}$ As the court said,

[o]n the record before us... we conclude that [plaintiff] has not satisfied his burden of demonstrating that video games are or contain protected expression.... [H]e has failed to demonstrate that video games import sufficient communicative, expressive or informative elements to constitute expression protected under the First Amendment .... [1]t appears that any communication or expression of ideas that occurs during the playing of a video game is purely inconsequential. [Plaintiff] has succeeded in establishing only that video games are more technologically advanced games than pinball or chess. That technological advancement alone, however, does not impart First Amendment status to what is an otherwise unprotected game. ${ }^{226}$

Two other Massachusetts cases in the same year also examined the first amendment status of video games. Marshfield Family Skateland, Inc. v. Town of Marshfield ${ }^{227}$ was also heard by the Massachusetts Supreme Court. It grew out of a complete prohibition by the town of Marshfield on the commercial operation of coin-activated amusement machines. ${ }^{228}$ Faced with the holding in Caswell, the Marshfield plaintiffs attempted to show that the video games they intended to make available to their customers, Ms. Pac-Man, Tron, Donkey Kong, Zaxxon, and Kangaroo, were sufficiently expressive as to merit protection. ${ }^{229}$ The court was unimpressed, but did recognize the potential that some future games might be protected: "We recognize that in the future video games which contain sufficient communicative and expressive elements may be created. We are not prepared in this case, however, to hold that these video games, which are, in essence, only technologically advanced pinball machines, are entitled to constitutional protection." ${ }^{230}$

223. See Caswell v. Licensing Comm'n, 444 N.E.2d 922, 922-23 (Mass. 1983).

224. See Caswell, 444 N.E.2d at 925.

225. See id. at $925-26$.

226. Id. at 926-27.

227. 450 N.E.2d 605 (Mass. 1983).

228. See Marshfield Family Skateland, Inc. v. Town of Marshfield, 450 N.E.2d 605, 60607 (Mass. 1983).

229. See Marshfield Family Skateland, 450 N.E.2d at 609.

230. Id. at 609-10. 
The third Massachusetts case was brought in federal court but to no greater success. Malden Amusement Co. $v$. City of Malden ${ }^{231}$ again challenged the denial of a license, this time to operate fifty machines in an arcade. Again, the plaintiff claimed the protection of the First Amendment for his venture, and again the court refused to bring video games under the umbrella of the Free Expression Clauses. ${ }^{232}$ The court noted the decision and reasoning of the federal court in America's Best, found that reasoning persuasive, and adopted the conclusion of that court. ${ }^{233}$

Similar reasoning has been used to uphold regulations prohibiting games, including video games, from establishments within two hundred feet of an elementary or secondary school ${ }^{234}$ and, most interestingly in People $v$. Walker, ${ }^{235}$ affirming a conviction for allowing juveniles to play video games, in violation of a city ordinance prohibiting any youth under seventeen from "any public association or involvement with electronic video games without his parent or guardian being present."236 The Walker court specifically adopted the analysis of the Marshfield court, and like that court recognized the contingent nature of the conclusion and the possibility that future video games might be sufficiently expressive or communicative to merit protection. ${ }^{237}$ If a general prohibition on those under seventeen playing video games is constitutional, a prohibition on those same youths playing first person shooter video games should also be constitutional.

There is a gap in the case law, until the 1991 case Rothner $v$. City of Chicago, ${ }^{238}$ which deserves particular mention, because of the judges

231. 582 F. Supp. 297 (D. Mass. 1983).

232. See Malden Amusement Co. v. City of Malden, 582 F. Supp. 297, 299 (D. Mass. 1983).

233. See Malden Amusement, 582 F. Supp. at 299.

234. See, e.g., Tommy \& Tina, Inc. v. Dep't of Consumer Affairs, 459 N.Y.S.2d 220 (N.Y. Sup. Ct.), affd, 464 N.Y.S.2d 132 (N.Y. App. Div. 1983), affd, 464 N.E.2d 988 (N.Y. 1984).

235. 135 Mich. App. 267, 354 N.W.2d 312 (1984).

236. People v. Walker, 135 Mich. App. 267, 270, 354 N.W.2d 312,314(1984)(citations omitted).

237. See Walker, 135 Mich. App. at 274-75, 354 N.W.2d at 316-17.

238. 929 F.2d 297 (7th Cir. 1991). 
involved..$^{239}$ The United States Court of Appeals for the Seventh Circuit, with Judge Ripple writing, but with Judge Posner, who rejected the Indianapolis limitations on violent video game play by minors, on the panel, examined a Chicago ordinance prohibiting minors from playing video games during school hours. ${ }^{240}$ The plaintiff, operator of a video arcade, had claimed first amendment protection for video games in general, and the court rejected the broad claim, while leaving open the possibility that some games are protected. ${ }^{241}$

We are aware that several district courts, ruling in a variety of factual contexts and upon requests for preliminary injunctions, have held that video games are not protected by the first amendment. However, these cases do not hold that, under all circumstances, all video games can be characterized as completely devoid of any first amendment protection. On the basis of the complaint alone, we cannot tell whether the video games at issue here are simply modern day pinball machines or whether they are more sophisticated presentations involving storyline and plot that convey to the user a significant artistic message protected by the first amendment [sic]. Nor is it clear whether these games may be considered works of art. To hold on this record that all video games-no matter what their content-are completely devoid of artistic value would require us to make an assumption entirely unsupported by the record and perhaps totally at odds with reality. ${ }^{242}$

The court did not have to decide whether the specific games involved were worthy of first amendment protection because it could uphold the ordinance as a time, place, or manner restriction, even if free expression were implicated, but it clearly left open the possibility that some advanced games may be protected. ${ }^{243}$

239. There is a case involving the game Dungeons \& Dragons that could be taken as filling some of the latter part of the gap. The case involved a tort suit by the mother of a child who was obsessed with the game and committed suicide. See Watters v. TSR, Inc., 715 F. Supp. 819 (W.D. Ky. 1989), aff'd, 904 F.2d 378 (6th Cir. 1990). Without analyzing the video game cases, the judge concluded that Dungeons \& Dragons, "whether it is classified as literature or merely a game, falls within the class of publication which is generally afforded protection under the first amendment." Watters, 715 F. Supp. at 821 . The appellate court found it unnecessary to reach the first amendment issue and it affirmed on state tort law grounds. See Watters v. TSR, Inc., 904 F.2d 378, 380 (6th Cir. 1990).

240. See Rothner v. City of Chicago, 929 F.2d 297, 298 (7th Cir. 1991).

241. See Rothner, 929 F.2d at 302-03.

242. Id. at 302-03 (footnote omitted).

243. See id. at 303. 


\section{B. Modern Games}

Ten years after Rothner, the issue was again addressed, this time by the district court in the Indianapolis case. ${ }^{244}$ The video game industry again claimed that advances in video games had brought with them first amendment protection. ${ }^{245}$ The court looked at the evidence offered and concluded that the record supported the claim that at least some video games contain protected expression. ${ }^{246}$ At least, the court believed it could not deny a preliminary injunction based on the city's claim that all video games lie outside the scope of the First Amendment. ${ }^{247}$ The appellate court noted the position taken by the trial court, but did not offer its own analysis on this point. ${ }^{248}$ The force of the district court's position may be limited by the fact that the issue was not central to the ruling. The trial judge used the violence as obscenity theory in refusing to issue the injunction, so the only effect of the decision on protection was to require an examination of the obscenity issue. ${ }^{249}$ All that being said, however, it is the first case of a court coming to the conclusion it did.

A recent law review note also took up, in an analysis of the difficulties faced in violent video game tort suits, the Rothner invitation to argue that modern video games deserve protection and presaged the American Amusement district court ruling to that effect. ${ }^{250}$ The note contends that the earlier decisions, decided in the "embryonic stages of video game development," are no longer applicable to the more sophisticated games of today. ${ }^{251}$ "Designers today rely on full-motion video, detailed animation, and stereo surround sound to bring their storyline, plots, and characters to life. Today's games are able to simulate real-world environments . . . and vivid fantasy worlds."252 That would seem true, but it does not necessarily follow that courts will view the modern games as different in kind from the embryonic games; they may be seen as simply far more complex pinball machines. While there is expression in writing the code that controls the

244. See Am. Amusement Mach. Ass'n v. Kendrick, 115 F. Supp. 2d 943 (2000) [hereinafter Am. Amusement Mach. I], rev'd, 244 F.3d 572 (7th Cir.), cert. denied, 534 U.S. 994 (2001).

245. See Am. Amusement Mach. I, 115 F. Supp. 2d at 950.

246. See id. at $952,954$.

247. See id. at 954.

248. See Am. Amusement Mach. Ass'n v. Kendrick, 244 F.3d 572, 574 (7th Cir.) [hereinafter Am. Amusement Mach. II], cert. denied, 534 U.S. 994 (2001).

249. See Am. Amusement Mach. Ass'n II, 244 F.3d at 574.

250. See David C. Kiernan, Shall the Sins of the Son Be Visited upon the Father? Video Game Manufacturer Liability for Violent Video Games, 52 HastingS L.J. 207 (2000).

251. Id. at 218.

252. Id. 
games and the result may have artistic content, there is still the difference between seeing and hearing a story presented in any medium and the activity present in pinball machines and video games.

The note offers other arguments for protection, but those arguments do not seem to distinguish the ultra-modern from the not-too-much earlier games. Video games are said to play a role in developing the future electorate "by the 'subtle shaping of thought which characterizes all artistic expression." "253 But, many experiences, probably all experiences, play a role in shaping thought. Having been in an automobile accident affects the way a person thinks about traffic safety issues, but it would be odd to characterize accidental collision as communication. The fact that communication affects character does not mean that everything that affects character is communication. As long as courts continue to see video games primarily as an activity rather than an attempt by the designer to communicate, the games may not enjoy first amendment protection.

That is the position taken by Judge Limbaugh. ${ }^{254}$ To find video games to be a form of speech or expression requires, he wrote, that "there must exist both an intent to convey a particularized message and a great likelihood that this message will be understood. . . . [T] here must be some element of information or some idea being communicated in order to receive First Amendment protection."255 While the First Amendment does apply to entertainment such as film, that is because, as the Supreme Court said, the line between entertaining and informing is too elusive to allow a conclusion that entertainment, which does communicate, is not protected as a way of informing. ${ }^{256}$ Where there is no intent to or likelihood of passing information or communicating a message, even the principle that entertainment is protected does not apply.

253. Id. at 219 (quoting Joseph Burstyn, Inc. v. Wilson, 343 U.S. 495, 501 (1952)).

254. See Interactive Digital Software, 200 F. Supp. 2d at 1132.

255. Id. at 1132 (citations omitted). Several recent opinions in tort suits address this issue and come down in favor of the video game industry. Sanders v. Acclaim Entertainment, Inc., 188 F. Supp. 2d 1264 (D. Colo. 2002), simply relies on Am. Amusement Mach. II's assumption that at least some games are protected with no significant further analysis. Two other recent cases come to the same conclusion and provide additional analysis. See, e.g., James v. Meow Media, Inc., 300 F.3d 683, 696 (6th Cir. 2002), cert. denied, U.S. , $123 \mathrm{~S}$. Ct. 967 (2003); Wilson v. Midway Games, Inc., 198 F. Supp. 2d 167 (D. Conn. 2002). Both were tort cases, and both courts took the allegations of liability to be directed at the messages conveyed by the games. See James, 300 F.3d at 695; Wilson, 198 F. Supp. 2d at 169, 181. The messages are part of the entertainment and would be protected, and the cases indicate that any limitations must be directed at the play aspects of video games rather than at limiting the story lines. See James, 300 F.3d at 698-99; Wilson, 198 F. Supp. 2d at 181. See also infra note 306 and accompanying text.

256. See Winters v. New York, 333 U.S. 507, 510 (1948). 
The court reviewed a number of video games and "found no conveyance of ideas, expression, or anything else that could possibly amount to speech."257 In the court's view, video games are more like sports or board games than like film or television. ${ }^{258}$ Earlier courts determined that bingo was not protected by the First Amendment for that same lack of communication, ${ }^{259}$ and the St. Louis court saw no reason to reach a different conclusion simply because modern technology was used to present a game in video form. ${ }^{260}$ Similarly, the court noted that baseball may be accompanied by expression, but is itself a game and not expression and does not become expression simply because it is the virtual baseball of a video game. ${ }^{261}$ Nor, the court said, does the addition of violence add expression; boxing is no more expression than baseball. ${ }^{262}$

\section{Improved Story Lines Not Enough}

The basis for the earlier suggestion that video games might one day become protected was that the storylines would become more complex and eventually reach a level of expression deserving of constitutional protection. But, it is not as though earlier video games had no story. Pac-Man was a story of a rather happy looking and multi-lived entity being pursued by ghosts around a maze. Fortunately for Pac-Man, there were power pills that gave him the ability to devour his pursuers. Frogger was a story about a frog trying to cross a street without being hit by a vehicle or a river by hopping from log to log. Neither story constitutes anything resembling great literature, but being great literature is not a requirement for first amendment protection. The written work of the worst hack novelist is just as protected as that of Nobel Prize winners.

Judge Limbaugh recognized this equality in the eyes of the First Amendment:

This Court has difficulty accepting that some video games do contain expression while others do not, and it finds that this is a dangerous path to follow. The First Amendment does not allow us to review books, magazines, motion pictures, or music and decide that some of them are speech and some of them are not. It appears to the

257. Interactive Digital Software, 200 F. Supp. 2d at 1134.

258. See id.

259. See, e.g., There To Care, Inc. v. Comm'r of the Ind. Dep't of Revenue, 19 F.3d 1165,1167 (7th Cir. 1994); Allendale Leasing, Inc. v. Stone, 614 F. Supp. 1440, 1454 (D.R.I. 1985), aff'd, 788 F.2d 830 (1 st Cir. 1986).

260. See Interactive Digital Software, 200 F. Supp. $2 d$ at 1134.

261. See id.

262. See id. at 1134-35. 
Court that either a "medium" provides sufficient elements of communication and expressiveness to fall within the scope of the First Amendment, or it does not. ${ }^{263}$

The judge raises a real concern. To allow first amendment protection to be determined by some official's, even a judge's, view as to the complexity of the story is to open the door to government abuse. ${ }^{264}$ It may be far easier to decide that a dissident theory is too simplistic to be deserving of protection than it is to decide that it presents a clear and present danger. It must be something about the medium, or at least the way in which the medium is used, that determines protection, not the complexity of the story the medium conveys.

\section{Video Games as Non-communication}

Consider a prosecution of a house of prostitution in which the defendants assert a first amendment claim. They point to the use of fantasy rooms and claim to have written a variety of complex scripts in the context of which the prostitutes engage their customers. The existence of costumes, scenery, and scripts do not change the fundamental nature of the transaction, and the First Amendment should not serve to protect this otherwise regulable activity.

As perhaps a better example, consider a paint ball operation in which players use firearms that propel a plastic projectile full of paint and engage in war games. That would seem to be an activity that would not merit first amendment protection. It is a game, not the communication of ideas. As such, it is not the sort of human endeavor the First Amendment was designed to protect. Now suppose that instead of two teams of players renting the weapons and arena, the arena operators supply one of the teams. The paying team of customers "fights" the arena team, and the arena operators put great effort into designing the layout and scripting the actions and reactions of its own team. Even that effort would seem not to extend the umbrella of first amendment protection to the actual activity of engaging in paint ball.

When the state has an interest in regulating an activity that might be argued to be expressive, the Supreme Court has made it clear that the interest must be in the acts involved rather than in what the acts may communicate. ${ }^{265}$

263. Id. at 1134 .

264. The existence of serious, literary, artistic, political, or scientific value does play an important role in the obscenity test of Millerv. California, 413 U.S. 15 (1973). There, however, serious value serves to place back under the protection of the first amendment material that otherwise meets the test for obscene content. Material is not excluded from the Expression Clauses just because it is not sufficiently good or serious but because it appeals to the prurient interest, is patently offensive, and depicts acts specifically defined by statute. See Miller v. California, 413 U.S. 15, 24 (1973).

265. See United States v. O'Brien, 391 U.S. 367 (1968). 
If the state's interest is in prohibiting commercial sex or in preventing injury to paint ball players, that should not raise first amendment problems. It is when the state is instead motivated by a desire to suppress the scripts themselves that there is a clear free expression violation.

The case for video games should, in fact, be easier than the examples. In the examples, there is another person, prostitute or player, involved and what might conceivably count as communication with that person. The prostitute's customer, in reacting to the setting and script, communicates some message that, in conjunction with alternative available scripts, tells the prostitute how the action is to continue. Similarly with the paint ball example; the actions of the players trigger one of a number of available reactions or scripts from the management team. The player's actions told the game provider what the player wanted to do, and the provider responded accordingly. With an ordinary arcade video game, there is no one with whom the player can communicate. It is only a machine, and while the programmer may communicate to the player through the software, the player's actions do not communicate back to the programmer but only to the program. A game involving two or more players, as in a multi-player arcade game or more likely an on-line game, would involve person-to-person communication. The multiplayer video game, however, should be no more protected by the First Amendment than the fantasy sex or paint ball examples or a game of baseball, checkers, or tennis. The only personal interactions are simply moves of the game intended to win, rather than to convey any message.

Programmers would likely respond that there is great creativity in the development of the code involved in making the games operate and that such creativity deserves protection. They are clearly right on the first claim, but the second claim is not as certain. The United States Court of Appeals for the Second Circuit recently considered the first amendment status of computer code in Universal City Studios, Inc. v. Corley, ${ }^{266}$ a case arising under the Digital Millennium Copyright Act (DMCA). ${ }^{267}$ The case grew out of Corley posting on his website a decryption code for the encryption that protects DVD movies from being copied. ${ }^{268}$ The DMCA prohibits providing technology capable of circumventing digital walls set up by copyright owners, and the film industry sought an injunction against Corley. ${ }^{269}$ As one of his responses, Corley claimed that his posting of the code was protected by the First

266. 273 F.3d 429 (2d Cir. 2001).

267. See Digital Millennium Copyright Act, Pub. L. No. 105-304, 112 Stat. 2860 (1998) (codified as amended in scattered sections of $5,28,35, \& 17$ U.S.C.).

268. See Universal City Studios, Inc. v. Corley, 273 F.3d 429, 435-436 (2d Cir. 2001).

269. See Universal City Studios, 273 F.3d at 435. 
Amendment, and the court was faced with the question of the status of computer code as speech. ${ }^{270}$

The court recognized that code can merit protection and that code is in some sense like mathematical formulae or musical scores, capable of carrying messages to those conversant in the symbolic language, and the obscurity of the language should not be of constitutional relevance. ${ }^{271}$ According to the Court, "[i]f someone chose to write a novel entirely in computer object code by using strings of 1 's and 0 's for each letter of each word, the resulting work would be no different for constitutional purposes than if it had been written in English."272 Computer code, of course, also causes computers to perform functions, but the court would not allow that to deprive code of first amendment protection. Such code is also understandable by a human programmer and thus can convey information and merits protection, but the scope of the protection still required analysis.

Corley argued that code is similar to blueprints or recipes that communicate methods of accomplishing goals or tasks, but the court disagreed. ${ }^{273}$

Unlike a blueprint or a recipe, which cannot yield any functional result without human comprehension of its content, human decision-making, and human action, computer code can instantly cause a computer to accomplish tasks.... [The] realities of what code is and what its normal functions are require a First Amendment analysis that treats code as combining nonspeech and speech elements, i.e., functional and expressive elements. ... We recognize ... that the functional capability of computer code cannot yield a result until a human being decides to insert the disk containing the code into a computer and causes it to perform its function .... Nevertheless, this momentary intercession of human action does not diminish the nonspeech component of code, nor render code entirely speech. ${ }^{274}$

The DMCA's proscription against posting a decryption code targeted only the nonspeech aspects of the code. It was unconcerned with providing information to a human but only with providing a tool that could cause a computer to execute a particular task, and that target of functional capacity was not aimed at the speech aspects of the computer code. ${ }^{275}$

Code written by video game developers should merit more first amendment protection than the decryption code. The decryption code may have conveyed information to programmers, but its primary, almost exclusive, use was to decrypt. The code for video games is more clearly aimed at

270. See id. at 436.

271. See id. at $445-46$.

272. Id. at $445-46$.

273. See id. at 451.

274. Id.

275. See Universal City Studios, 273 F.3d at 454. 
conveying information or expression to human beings. It also, however, does have a functional role.

In addition to providing a storyline and setting, video game code causes the computer to operate for the player to accomplish tasks against that background. If video games simply involved putting in a quarter and watching a story unfold on the screen, the game would be protected, and it should make no difference that the images are produced through the operation of code instead of the projection of light through celluloid. The developer is still providing communication to a human recipient, and that is protected, whatever the medium.

The aspects of the code that allow for human participation in the game, however, are a different story. That part of the code is not read or viewed by the player and conveys no information to him or her. Rather, that part of the code is functional. It causes the program to skip to a particular spot to continue the action, depending on what the action of the player was. Arguably, skipping to a spot in the program could also be protected. If a video game did not show the same story each time a quarter was inserted but randomly chose different options at various points in the story, that is no less the conveyance of expression to a human. But, the player's selection of the next part of the story is not communication to anyone. There is, at that time, no other human involved, and the player in firing the weapon in a first person shooter game is no more speaking, in a first amendment sense, than is a computer operator who inserts a disk to run any other program.

There is an available and seemingly strong response to this conclusion. A person conducting research on a computer, accessing a database, would seem to be in the same situation as the video game player. The researcher's requests for materials are not conveyed to a human being, so there is no communication in that direction, in the same sense that there is no communication from the video game player to any human. If there is to be a distinction, it must be in the activity in which the two are engaged. The researcher's work that is the goal of the request is itself protected by the First Amendment. Research, as a step to knowledge, merits the full protection of the Amendment. The game player's response to the machine is not research but a part of a game, and if it is protected, so are pinball, bingo, and baseball.

On the other hand, a person faced with a novel with a choice of ending also does not communicate to another human. If on page eighty, the reader is given the opportunity to go to page eighty-one if he or she wants a tragic ending or to page three hundred if a happy ending is desired, the choice and the medium in which it is given would seem to be protected in the same way 
in which the selection of the book in the first place would be protected. ${ }^{276}$ The situation would seem to be the same where the selection of continuing storyline is made in an electronically based medium. In response, just because a choice must be allowed does not mean that all ways in which to make the choice are protected. A novelist may be free to send a variable book chapter by chapter, with the reader communicating what sort of next chapter is desired, but that does not make all ways of conveying the choice protected. Clearly, the state is not barred from forbidding nonspeech acts, just because a novelist might respond to the acts by sending a chapter in an unfolding story. The firing of a weapon in a first person shooter game is an act that has a function rather than one that serves to communicate. As long as the state's interest is in limiting the act rather than controlling the story, the limit should not violate the First Amendment.

As long as the state does not ban children from watching the story presented by the video game, its focus would seem to be on an act that is not a part of any human to human communication. Any second amendment problems aside, a ban on children shooting on a target range would not raise first amendment problems. That should be true even if the operator gave away books for prize winning performances. The same should hold for a video shooting game, where the prize is the continuation of the story in a particular direction. As long as it is the shooting activity that gives rise to the concern and is the sole limitation, rather than the content of the story, the First Amendment should not bar the regulation of access by children to first person shooter games.

That conclusion may be argued so far to apply only to the current generation of video games. As internet versions or two player arcade games develop, there will be two or more people involved in the game. One player's action will not be communicated solely to a computer code bringing about a shift in storyline. It will cause an effect on another player's screen, and that might be argued to be communication to the other player. But, if that serves to provide first amendment protection, all games, with the exception of solitaire, would seem equally protected. When a batter in baseball hits a ball, it causes actions by the other team's fielders. When a chess player moves a piece, it causes his or her opponent to make a counter move. But neither the hit ball nor the moved chess piece is communication; they are both just acts that are part of the game. So too for the video game player's action, even in a next generation game.

276. The same point could be made for improvisational comedy, in which the audience suggests the next part of the vignette, or for any other sort of interactive theater. 


\section{IMPLEMENTING THEORY}

\section{A. First Amendment Values}

Judge Posner, in his American Amusement Machine Ass' $n v$. Kendrick ${ }^{277}$ opinion, argued that Indianapolis could not limit children's access to violent video games, even in support of parents' wishes that they not play. He said that children have first amendment rights and that those rights are independent of any rights of their parents. ${ }^{278} \mathrm{He}$ saw the enforcement of the limitation, even in support of parental control over influences on their children, as the imposition of an orthodoxy government could not be allowed to further. ${ }^{279}$ In very colorful language, the court raised the specter of such regimented thinking leading to " $[t]$ he murderous fanaticism displayed by young German soldiers in World War II, alumni of the Hitler Jugend." 280

Interestingly, Judge Posner was not far from the mark in his concern over Nazism, but he was coming from the wrong direction. Resistance Records, the label that produces musical groups such as RaHoWa (Racial Holy War), Nordic Thunder, and Angry Aryans and such titles as "Racially Motivated Violence" and "Race Riot," now offers a video game titled "Ethnic Cleansing."281 The player, after choosing to play the role of either a skinhead or member of the $\mathrm{KKK}$, moves through the streets of a virtual city killing gangs of "predatory sub-humans," Black and Hispanic characters, eventually entering the subways to attack the "sub-human" Jewish masters, end their plans for world domination, and save the White race, and this is not the only game of its ilk. ${ }^{282}$ The violence of much of the video game genre has been melded with bigotry to create a far more real danger of Nazism than Judge Posner's specter.

Despite the perhaps overblown rhetoric, Judge Posner does raise a serious issue regarding the age at which violent video game limitations should be addressed. As he put it, "[n]ow that eighteen-year-olds have the right to vote, it is obvious that they must be allowed the freedom to form their political views on the basis of uncensored speech before they turn eighteen, so that

277. 244 F.3d 572 (7th Cir.), cert. denied, 534 U.S. 994 (2001).

278. See Am. Amusement Mach. Ass'n v. Kendrick, 244 F.3d 572, 577 (7th Cir.) [hereinafter Am. Amusement Mach. II], cert. denied, 534 U.S. 994 (2001).

279. See Am. Amusement Mach. II, 244 F.3d at 578.

280. Id. at 577.

281. For a catalog of their offerings see http://www.resistance.com.

282. See http://www.resistance.com/ethniccleansing; Anti-Defamation League, Racist Groups Using Computer Gaming to Promote Violence Against Blacks, Latinos and Jews, at http://www.adl.org/videogames/default.asp (last visited Mar. 12, 2003). 
their minds are not a blank when they first exercise the franchise." ${ }^{.283}$ While it may be questionable how many violent video games one must play to be a competent voter, lines are better drawn on the basis of age than on content. Furthermore, the difference in an eighteen-year-old limitation and one set at an earlier age has been at least relevant in the Supreme Court's consideration of efforts to protect children. In Reno v. American Civil Liberties Union, ${ }^{284}$ the Court noted that the internet restrictions at issue there were broader than what had been acceptable in Ginsberg $v$. New York ${ }^{285}$ in part because Ginsberg prohibited sales to those under seventeen, while the internet regulations used eighteen as the relevant age. ${ }^{286}$ To avoid this concern, it would be advisable to impose any restrictions only on those under the age of seventeen.

Judge Posner also refused to accept, as a justification for Indianapolis' regulations, the support of parental desires to limit their children's access to violent video games. ${ }^{287} \mathrm{He}$ said that the eighteen-year-old's right to vote is his or her own right independent of parental rights. ${ }^{288}$ The right of the seventeenyear-old to form political opinions was, therefore, also independent of the parents' wishes, at least to the extent of limiting the state from being enlisted in the enforcement of those wishes. ${ }^{289}$ This conclusion may be questionable, given Ginsberg's willingness to allow the state to support parental limitations, but again Ginsberg was addressed to sales to those under seventeen, when the right need not be so independent. Ginsberg in conjunction with Reno, however, does suggest another limitation on statutes regulating access to violent video games. The Reno Court also distinguished the internet regulations there with the statute in Ginsberg by the fact that Ginsberg's statute did not restrict parental provision of the materials addressed, while the internet regulations limited everyone, parents included. ${ }^{290}$ In light of that distinction, it would be wise to include a provision under which parents may provide permission for their children to play in arcades, and parents should be allowed to buy violent video games for their children.

This combination of a "below the age of seventeen" age limit and allowing parents to make the choices that ought to be theirs for those younger than seventeen protects first amendment values while also protecting children. Below the age of seventeen, it recognizes the legitimate role parents play in

283. Am. Amusement Mach. II, 244 F.3d at 577.

284. 521 U.S. 844 (1997).

285. 390 U.S. 629 (1968).

286. See Reno v. ACLU, 521 U.S. 844, 865 (1997).

287. See Am. Amusement Mach. II, 244 F.3d at 578.

288. See id. at 577.

289. See id.

290. See Reno, 521 U.S. at 855. 
decisions as to the influences their children face. ${ }^{291}$ Ginsberg recognized that the state can help parents impose those decisions on their children. While the material at issue in Ginsberg was not protected by the First Amendment, when distributed to children, the extension of that result to violent video games under any of the theories offered has been the focus of this effort, and Ginsberg's willingness to help parents should carry over to this context and should also not be seen as damaging to the values behind the First Amendment. The legitimate issue of eighteen-year-old voting, whatever the relationship of playing violent video games to the exercise of that right, is protected by allowing the new voter a year in which the state does not impose even the parent's view as to what is suitable.

\section{B. Drafting Statutes}

The specific language of a statute limiting children's access to violent video games depends strongly on the theory the drafters believe is most likely to justify the limitations. While the suggestions as to age and parental permission are general, the rest of the drafting must be more tailored to theory. A jurisdiction within the seventh circuit would probably be ill advised to rely on the obscenity thesis. A better approach would be to base the statute on the harm that violent video games are seen as causing and making an effort to lay out a convincing case for that harm. While the seventh circuit was not impressed with the evidence offered, a better case might be made. Such a jurisdiction could instead draft a statute relying on the unprotected status of video games. The courts in the Indianapolis case assumed, but did not really decide, that video games were protected expression, and that issue could still be contested. ${ }^{292}$ A jurisdiction outside the seventh circuit might try either of

292. See Am. Amusement Mach. II, 244 F.3d at 572. 
the above approaches or still use the obscenity theory. ${ }^{293}$ Whatever theory is to justify the legislation, care must be given to what the theory says about the focus of the statute. Before turning to that issue, it should be noted that there is no need to rely on a single theory. A jurisdiction might instead choose to employ a combination of approaches by adopting separately two or three of the suggested statutes.

\section{Statutes Based on Harm}

If it is accepted that violent video games are protected by the First Amendment, and a statute is to be justified on the basis of the harm that violent video games do to the physical and psychological well-being of youth, the statute will have to be narrowly tailored to that harm. Given the reluctance of courts to accept the conclusions of social scientists regarding the aggression inducing effects of watching violent television or film, it would be wise to narrow limitations based on this theory to first person shooter games. While a court might accept the recent conclusions of the health care professionals and conclude that the general evidence is better established than it had been, the approach more likely to be successful would be to focus on the interactivity of shooting video games.

293. Other jurisdictions have considered the nature of violent depictions and the obscenity exception, and reliance on the theory might be less wise in those regions, although the analysis lacked the detail of the Seventh Circuit opinion and the option may be less closed. The Second Circuit, in Eclipse Enterprises, Inc. v. Gulotta, 134 F.3d 63 (2d Cir. 1997), struck down a local ordinance barring the sale to minors of trading cards depicting heinous crime, harmful to minors, defined as in the Indianapolis and St. Louis ordinances. In doing so, the court said that the standards that apply to violence and obscenity differ because obscenity is not protected speech, but did not examine whether the two should be distinct categories. See Eclipse Enters., Inc. v. Gulotta, 134 F.3d 63, 67 (2d Cir. 1997). A concurring opinion in Gulotta accepts the conclusion with no additional analysis, but does consider the analogy to obscenity reasonable. See Eclipse Enters., 134 F.3d at 69-70 (Griesa, J., concurring).

The Sixth Circuit, in James v. Meow Media, Inc., 300 F.3d 683 (6th Cir. 2002), cert. denied, U.S. 123 S. Ct. 967 (2003), also refused to include violence within its obscenity jurisprudence. It did so in the context of a tort suit and noted that the arguments of the plaintiffs did not address the concerns common to obscenity proscriptions, offense rather than danger. See James v. Meow Media, Inc., 300 F.3d 683, 695-99 (6th Cir. 2002). The conclusion may not apply as directly to a legislative determination that violent materials are unsuitable for children, but the decision would counsel caution using the approach in the Sixth Circuit as well.

There are also somewhat older cases, see, for example, Video Software Dealers Ass' $n$ v. Webster, 968 F.2d 684 (8th Cir. 1992) and Davis-Kidd Booksellers, Inc. v. McWherter, 866 S.W.2d 520 (Tenn. 1993), that have stated that there is a difference between violence and obscenity, but without any analysis of the arguments offered supra notes 133-210 and accompanying text. 
The strength of Grossman's conclusions is in the analogy to the methods used by the armed forces to increase firing rate and the provision of the skills necessary to be an effective killer. Any statute based on those conclusions would be limited to first person shooter games in which the targets are virtual humans or entities with human-like characteristics. A statute will have to be drafted carefully to define how human the targets must be. A simple shooting gallery game should not be included, so as to avoid a statute that lacks narrow tailoring. Rather, there must be some significant degree of anthropomorphization of any animals or aliens that serve as targets.

An important limitation to this justification is that it should not be employed to support statutes that limit watching others play the games. Watching others is more akin to watching television or film, and if courts are unwilling to approve bans in those media on the basis of the harm caused, they are unlikely to allow a ban on what is still the essentially passive activity of watching others play. If there is in fact a difference in the interactive video game, it is a difference that speaks to the player. It is the player who develops the deadly skills, and it is the player who rehearses the behavior in the virtual context and becomes more psychologically capable of engaging in similar behavior in the real world. Thus, unless a court is willing to split from earlier decisions and conclude that there is sufficient harm from aggression inducing effects in the passive viewing of violent video game play, the harm justification should be employed only for statutes addressing play by minors.

\section{Statutes Based on Violence as Obscene}

Statutes based on the conclusion that violent depictions can be obscene, at least when children are the viewers, can address not only players but also minors who watch others play. Since the justification relies on an extension of Ginsberg and the test for obscenity found in Miller $v$. California, ${ }^{294}$ a statute should be guided by those cases. Some changes in the Miller test, which asks:

(a) whether "the average person, applying contemporary community standards" would find that the work, taken as a whole, appeals to the prurient interest; (b) whether the work depicts or describes, in a patently offensive way, sexual conduct specifically defined by the applicable state law; and (c) whether the work, taken as a whole, lacks serious literary, artistic, political, or scientific value[,] $]^{295}$

294. 413 U.S. 15 (1973).

295. Miller v. California, 413 U.S. 15, 24 (1973) (quoting Roth v. United States, 354 U.S. 476, 489 (1957)) (citations omitted). 
are required, since Miller addressed sex and the current concern is violence. Other changes in the wording of the Miller test are necessitated by the fact that the statute is addressed to obscenity as to children, just as Ginsberg required adaptation in the language of the then existing test for sexual obscenity.

The first change is in the first prong, since "prurient" speaks to sex. The Court had earlier, in Roth $v$. United States, ${ }^{296}$ defined the word as meaning "material having a tendency to excite lustful thoughts"297 and cited a dictionary definition as "[i]tching; longing; uneasy with desire or longing; of persons having itching, morbid, or lascivious longings; of desire, curiosity, or propensity, lewd." ${ }^{298}$ The equivalent of a prurient interest in sex has been taken to be a "morbid interest in violence," 299 since both seem to indicate something that goes beyond simple curiosity or casual interest. The community standards aspect of the first prong also has to be refocused on minors, or as suggested those under seventeen, so the first prong should require that the average person, applying contemporary community standards finds that the game, as a whole, appeals to a morbid or perhaps depraved interest in violence for those under seventeen.

The second prong requires specificity in the on-screen images addressed and again needs a focus on minors. A statute would have to require a finding that the game depicts acts in a way that is patently offensive under contemporary community standards as to what is suitable for those under seventeen. The statute must also specifically define the conduct or acts addressed. The Indianapolis ordinance listed "realistic serious injury to a human or human-like being where such serious injury includes amputation, decapitation, dismemberment, bloodshed, mutilation, maiming or disfiguration" 300 and the St. Louis ordinance employed the same language. ${ }^{301}$ Both these lists would seem to exclude the killing of a human, if unaccompanied by bloodshed, amputation, etc. The bill in the House of Representatives did include killing by use of a lethal weapon or in hand to hand combat and aggravated assault or battery, which seem like reasonable

296. 354 U.S. 476 (1957).

297. Roth v. United States, 354 U.S. 476, 487 n.20 (1957).

298. Roth, 354 U.S. at 487 n.20 (citations omitted).

299. This was the language in the Indianapolis ordinance, see American Amusement Machine Ass' $n$ v. Kendrick, 115 F. Supp. 2d 943, 946 (S.D. Ind. 2000), rev'd, 244 F.3d 572 (7th Cir.) [hereinafter Am. Amusement Mach. I], cert. denied, 534 U.S. 994 (2001) (citations omitted), as well as in the St. Louis ordinance, see Interactive Digital Software Ass' $n v$. St. Louis County, 200 F. Supp. 2d 1126, 1130 (E.D. Mo. 2002) (citations omitted).

300. Am. Amusement Mach. I, 115 F. Supp. 2d at 946 (citations omitted).

301. See Interactive Digital Software, 200 F. Supp. 2d at 1130. 
additions, but went on to include prostitution and illegal drug use. ${ }^{302}$ These latter two additions would seem difficult to justify under the theories presented here and might better be omitted and the focus left on violent crimes.

The language in the two ordinances designed to meet the second prong of Miller may also be argued to be unconstitutionally vague. But, both district courts considered and rejected that claim, finding the definitions provided were no more vague than those validated for sexual obscenity under Miller. ${ }^{303}$ The St. Louis ordinance also incorporated the video game industry's own rating system as rebuttable presumptions. Games rated as unsuitable for those under seventeen would be presumed harmful to minors for purposes of applying the ordinance, while those rated for a younger audience would be presumed not harmful to minors. ${ }^{304}$ The industry objected to what it saw as a delegation of legislative power to its own rating boards, but the court rejected the challenge, noting that the ordinance did itself provide a definition and only adopted the industry ratings as rebuttable presumptions. ${ }^{305}$ The tactic of reference to the industry rating system is a useful one in meeting scienter requirements. If the arcade operator or retailer must be shown to have known the nature of the video games involved, allowing a defense of good faith reliance on the standards will exonerate the merchant who did not realize the nature of the material. Employed in the other direction, the mature or adult only rating is probably less justifiable as a presumption that the material violates the ordinance or statute than as a presumption of scienter, and a jury should be required to itself find that the game does meet the statutory definition.

Lastly, the savings clause of the Miller test must be retained, although it should again be refocused on minors. Even if a video game does appeal to a morbid interest on the part of children in violence and goes beyond community standards of offensiveness as to what is suitable for children, a game should still be protected if it has serious value for children. If a game, taken as a whole, has serious literary, artistic, political, or scientific value for those under seventeen, it should not be considered obscene as to minors and its play could not be proscribed under this theory.

302. See H.R. 4645, 107th Cong. (2d Sess. 2002).

303. See Interactive Digital Software, 200 F. Supp. 2d at 1139-40; Am. Amusement Mach. I, 115 F. Supp. 2d at 978-80.

304. See Interactive Digital Software, 200 F. Supp. 2d at 1130-31.

305. See id. at 1139. 


\section{Statutes Based on Video Games as Unprotected}

Justifying a statute based on the theory that video games are unprotected, assuming a court accepts the theory, would seem the easiest path; that is, if the First Amendment does not protect video games, it should have little to say about the proper dimensions of a statute. Drafting, however, would not be as simple as it might at first appear. It must be remembered that the theory recognizes a distinction between the storyline, which is more akin to the entertainment of film, television, or the novel and enjoys first amendment protection, and the play of the game. ${ }^{306}$

Like a statute motivated by or justified under the first theory, the harmful effects of player interactivity, a limitation under this last theory would be justified only with regard to play and not to viewing either a story or the play of others. Furthermore, such a statute must focus on the actions involved rather than on the story context. An ordinance that prohibits children from playing video games involving virtual weapons or shooting would, under the analysis provided herein, not raise first amendment concerns. An ordinance that addressed shooting in the context of human targets would present a focus on the story and could raise such concerns. If it is the story line that is the focus of the statute, one of the first two theories must be employed; if it is purely the actions involved in playing the game, the third theory can serve to justify such restrictions.

\section{CONCLUSION}

While attempts to limit the access of minors to materials containing depictions of violence have not met with great past success, first person shooter violent video games may be sufficiently different to allow restriction. The outcome is by no means assured, but a court may find that such games are a greater danger to the physical and psychological well being of youth so that a statute narrowly tailored to the first person shooter games with human or human like targets can survive strict scrutiny. Alternatively, a court may, like the district court in the Indianapolis case, determine that our society's focus of obscenity law over somewhat more than the last century is misguided and that the exception should include the modern violent images that many find far more offensive than sexual images. Lastly, the true nature of video games, as games rather than as a form of communication, may lead a court, like the district court in the St. Louis case, to deny first amendment protection to the

306. See supra note 263-76 and accompanying text. 
actual play of the games while protecting design and story and allow restrictions on video shooting activities by youth. 